\title{
Photoactive Peptides for Light Initiated Tyrosyl Radical Generation and Transport into Ribonucleotide Reductase
}

\author{
Steven Y. Reece, ${ }^{\dagger}$ Mohammad R. Seyedsayamdost ${ }^{\dagger}{ }^{\top}$ JoAnne Stubbe $^{*}{ }^{\dagger, \S}$ and Daniel G. Nocera*${ }^{\dagger}{ }^{\dagger}$ \\ Departments of Chemistry ${ }^{\dagger}$ and Biology ${ }^{\S}$, Massachusetts Institute of Technology, 77 \\ Massachusetts Avenue, Cambridge, MA 02139-4307 \\ stubbe@mit.edu; nocera@mit.edu
}

\begin{abstract}
The mechanism of radical transport in the $\alpha 2$ (R1) subunit of class I E. coli ribonucleotide reductase (RNR) has been investigated by the photo-triggered generation of a tyrosyl radical, $\bullet Y 356$, on a 20 -mer peptide bound to $\alpha 2$. This peptide, Y-R2C19, is identical to the C-terminal peptide tail of the $\beta 2$ (R2) subunit and a known competitive inhibitor of binding of the native $\beta 2$ protein to $\alpha 2$. $\bullet$ Y356 radical initiation is prompted by excitation $(\lambda \geq 300 \mathrm{~nm})$ of a proximal anthraquinone, Anq, or benzophenone, BPA, chromophore on the peptide. Transient absorption spectroscopy has been employed to kinetically characterize the radical-producing step by time-resolving the semiquinone anion $\left(\mathrm{Anq}^{\bullet^{-}}\right)$, ketyl radical $(\bullet \mathrm{BPA})$ and $\mathrm{Y} \bullet$ photoproducts on (i) BPA-Y and Anq-Y dipeptides and on (ii) BPA/Anq-Y-R2C19 peptides. Light initiated, single turnover assays have been carried out with the peptide/ $\alpha 2$ complex in the presence of $\left[{ }^{14} \mathrm{C}\right]-$ labeled cytidine $5^{\prime}$-diphosphate substrate and ATP allosteric effector. We show that both the Anq and BPA containing peptides are competent in deoxycytidine diphosphate formation and that turnover occurs via Y731 to Y730 to C439 pathway-dependent radical transport in $\alpha 2$. Experiments with the Y730F mutant exclude a direct superexchange mechanism between C439 and Y731 and they are consistent with a PCET model for radical transport in which there is a uni-directional transport of the electron and proton transport among residues of $\alpha 2$.
\end{abstract}




\section{Introduction}

Correlated electron and proton motion is exquisitely controlled and utilized in biology for energy conversion. ${ }^{1}$ Whether the electron or proton are indirectly coupled, such as they are for proton pumping across a membrane driven by electron transfer, ${ }^{2,3}$ or intimately coupled as they are for amino acid radical initiation and transport, ${ }^{4}$ the precise mechanism by which Nature has fine-tuned proton-coupled electron transfer (PCET) to achieve such remarkable reactivity remains largely undefined. ${ }^{5-8}$ To understand this coupling mechanism by PCET in natural systems better, our efforts have turned to the $\sim 35 \AA$ radical transport pathway in class I E. coli ribonucleotide reductase (RNR).

RNR plays a crucial role in DNA replication and repair by catalyzing the reduction of nucleoside diphosphates (NDPs) to deoxynucleoside diphosphates (dNDPs). ${ }^{9-11}$ The class I $E$. coli enzyme is composed of two homodimeric subunits designated $\alpha 2$ and $\beta 2$, and a complex between the two is required for activity. ${ }^{12} \alpha 2$ houses the binding sites for the substrates and effectors, which control the specificity and rate of nucleotide reduction. ${ }^{13-15} \beta 2$ harbors the diferric tyrosyl radical $(\bullet$ Y122) cofactor proposed to initiate nucleotide reduction by generating a transient thiyl radical $(\cdot \mathrm{C} 439)$ in the active site of $\alpha 2{ }^{16}$ The crystal structures of both $\alpha 2$ and $\beta 2$ have been solved independently ${ }^{17-19}$ and a docking model of the two proteins has been proposed $^{17}$ that places Y122 on $\beta 2$ at a distance $>35 \AA$ away from the C439 residue on $\alpha 2$. Recent PELDOR studies provide support for a long distance radical migration. ${ }^{20}$ Radical transport has been proposed to occur via a radical hopping mechanism involving the aromatic amino acid radical intermediates shown in Figure 1. ${ }^{1,4}$ Specifically, the radical is proposed to hop from $\cdot \mathrm{Y} 122 \rightarrow \mathrm{W} 48 \rightarrow \mathrm{Y} 356$ in $\beta 2$ to $\mathrm{Y} 731 \rightarrow \mathrm{Y} 730 \rightarrow \mathrm{C} 439$ in $\alpha 2$. Under physiological conditions, oxidation of these residues requires both the loss of a proton and an electron, implicating PCET ${ }^{4-}$ ${ }^{6}$ as the radical transport mechanism. Recently the first positive evidence that Y356 is a redox active amino acid on the pathway has been presented, ${ }^{21}$ along with trapping of the radical at position 356 using the non-natural DOPA amino acid. ${ }^{22}$ Notwithstanding, sampling of a 
kinetically competent intermediate $\mathrm{e}^{23-25}$ along a conformationally-gated reaction profile presents a challenge to directly detecting amino acid radical intermediates. ${ }^{26}$

To address the challenge of kinetically resolving radical transport, we have simplified the RNR construct by focusing on the radical transport in the $\alpha 2$ subunit by the approach depicted in Figure 2. Using solid-phase peptide synthesis, we have assembled the $\alpha 2$ binding determinant of $\beta 2$, the 19-mer C-terminal peptide tail (R2C19), containing the redox active Y356 (YR2C19). ${ }^{27,28}$ A photo-oxidant, appended proximate to Y356 (Figure 2, red circle) can be photoexcited to produce $\bullet Y 356$, which can then be translated into the C439 active site of $\alpha 2$. We have established the competency of this construct by using tryptophan as the photo-trigger of -Y356. ${ }^{29}$ Studies on W-Y dipeptides show that photoionization of W with UV light $(\lambda<290 \mathrm{~nm})$ irreversibly generates $\mathrm{W} \cdot$, which in turn oxidizes $\mathrm{Y}$ within the $\mathrm{pH}$ range relevant to $\mathrm{RNR}^{30}$ Excitation of the peptide- $\alpha 2$ complex in the presence of CDP substrate and ATP effector results in $\mathrm{dCDP}$ formation, demonstrating enzymatic activity is retained when the entire $\beta 2$ subunit is replaced by a photoactive peptide. ${ }^{29}$ However a significant drawback with tryptophan-based peptide constructs arises from the need for UV-light to excite the tryptophan. Deep UV excitation profiles fall within the absorption envelope of RNR, thus presenting a significant problem for the direct kinetic analysis of $\alpha 2$-bound peptides owing to inner-filter optical effects and protein instability.

Described herein is the development of peptide-based photo-oxidants of tyrosine that may be excited to the red spectral side of the protein absorption manifold. We have had previous success using amino acid model systems in which tyrosine is photo-oxidized by the MLCT excited states of $\operatorname{Re}(\mathrm{I})$ complexes, which absorb in the visible spectral region. ${ }^{31}$ But this model is not easily adapted to RNR investigations because the facile photo-oxidation of tyrosine requires the deprotonation of the phenol with $\mathrm{p} K_{\mathrm{a}}=10$ (in order to avoid the thermodynamic barrier ${ }^{32,33}$ confronting the formation of the protonated radical cation) and $\alpha 2$ is stable only to $\mathrm{pH} 8.5$. Tyrosine oxidation can be expedited by forming a hydrogen bond between the phenol and a base,${ }^{34-36}$ thus switching the photo-oxidation from ET to PCET. ${ }^{37}$ Following this lead, we sought 
to develop photo-oxidants that could fulfill the dual role of electron and proton acceptor for the rapid tyrosine oxidation required in phototriggering RNR and at the same time could be excited by light outside the RNR absorption manifold.

Both benzophenone and anthraquinone are strong triplet $n \pi^{*}$ excited state oxidants with the ability to oxidize amines, aliphatic alcohols, and even water, though sluggishly. ${ }^{38-42}$ Studies on the mechanism of phenol oxidation by carbonyl triplet excited states have resulted in a model wherein PCET occurs within a hydrogen-bonded exciplex. ${ }^{43}$ In this model, electron transfer from the phenol to the electronically excited carbonyl is kinetically coupled to proton transfer between the oxygen atoms of phenol and the photo-oxidant. We now report that the excitation of the benzophenone unnatural amino acid (BPA) or Anq chromophore (Anq) (see Chart 1) appended to the N-terminus of the $\mathrm{Y}-\mathrm{R} 2 \mathrm{C} 19$ peptide generates $\mathrm{Y} \bullet$. The kinetics for the time evolution of the radical has been investigated with transient absorption $(\mathrm{TA})$ spectroscopy. The $\left(\bullet \mathrm{BPA} / \bullet \mathrm{Anq}^{-}\right.$ )-Y• diradical on the R2C19 peptide is generated in the sub-nanosecond timescale at pH 7.5 and with excitation light of $\lambda>300-355 \mathrm{~nm}$. We also show that these peptides bind to $\alpha 2$ and induce $\mathrm{dCDP}$ formation upon excitation of the peptide- $\alpha 2$ complex. Mutation of Y730 to F in $\alpha 2$ inhibits RNR turnover, consistent with a PCET model for radical transport in $\alpha 2$ in which the proton and electron transfer occurs along a unidirectional pathway within $\alpha 2$.

\section{Experimental}

Materials. Anthraquinone-2-carboxylic acid (Anq-COOH), reduced $\beta$-nicotinamide adenine dinucleotide phosphate (NADPH), N-hydroxyurea, deoxycytidine (dC), cytidine-5' diphosphate (CDP), trifluoroacetic acid (TFA), adenosine 5'-triphosphate (ATP), 1-(3dimethylamino-propyl)-3-ethylcarbodiimide hydrochloride $\quad(\mathrm{EDC} \cdot \mathrm{HCl}), \quad$ piperidine, diisopropylethylamine (DIPEA), triisopropylsilane and N-methylmorpholine (NMM) were purchased from Sigma-Aldrich. 4-Benzoyl-N-[(9H-fluoren-9-ylmethoxy)carbonyl]-Lphenylalanine (Fmoc-BPA-COOH) and L-phenylalanine tert-butyl ester hydrochloride (F$\mathrm{O} t \mathrm{Bu} \cdot \mathrm{HCl})$ were from Advanced ChemTech. 1-Hydroxybenzotriazole (HOBt) and L-tyrosine 
tert-butyl ester (Y-OtBu) were obtained from NovaBiochem. O-(7-azobenzotriazol-1-yl)-1,1,3,3tetramethyluronium hexafluorophosphate (HATU), O-(1,1-dimethylethyl)-N-[(9H-fluoren-9ylmethoxy)carbonyl]-L-tyrosine (Fmoc-Y(tBu)-OH), and N-[(9H-fluoren-9-ylmethoxy)carbonyl]-L-phenylalanine (Fmoc-F-OH) were purchased from Applied Biosystems. $\left[2-{ }^{14} \mathrm{C}\right]-$ CDP was purchased from Moravek Biochemicals and diluted to a specific activity of 5455 $\mathrm{cpm} / \mathrm{nmol}$. Calf-intestine alkaline phosphatase $(20 \mathrm{U} / \mu \mathrm{L})$ was purchased from Roche. All chemicals were used as received, except for piperidine, which was freshly distilled from $\mathrm{KOH}$ under $\mathrm{N}_{2}$ prior to use. 4-Benzoyl-L-phenylalanyl-tyrosine methyl ester trifluoroacetic acid (BPA$\mathrm{Y}-\mathrm{OMe} \bullet \mathrm{TFA}$ ) was available from a previous study. ${ }^{44}$ E. coli thioredoxin (TR, SA of $40 \mathrm{U} / \mathrm{mg}$ ), E. coli thioredoxin reductase (TRR, SA of $1800 \mathrm{U} / \mathrm{mg}$ ) and E. coli $\beta 2$ (SA of $6800 \mathrm{nmol} / \mathrm{min}$ $\mathrm{mg}$ ) were isolated as previously described. ${ }^{45}$

N-[(9,10-Dihydro-9,10-dioxo-2-anthracenyl)carbonyl]-L-tyrosine (Anq-Y-OH). Anq$\mathrm{COOH}$ (300 mg, $1.19 \mathrm{mmol}, 1.0 \mathrm{eq}), \mathrm{Y}-\mathrm{O} t \mathrm{Bu}(282 \mathrm{mg}, 1.0 \mathrm{eq}), \mathrm{EDC} \cdot \mathrm{HCl}(250 \mathrm{mg}, 1.1 \mathrm{eq})$, and HOBt $(177 \mathrm{mg}, 1.1 \mathrm{eq})$ were combined in a $100 \mathrm{~mL}$ flask with $30 \mathrm{~mL}$ of DMF. NMM (530 $\mu \mathrm{L}$, 4.0 eq) was added and the solution was stirred overnight. The solvent was removed in vacuo, and the resulting oil was dissolved in $80 \mathrm{~mL}$ of methylene chloride. The organics were washed with 2 $\times 50 \mathrm{~mL}$ of water, dried over $\mathrm{MgSO}_{4}$, and filtered to remove the drying agent. The solvent was removed in vacuo to yield a yellow oil, which was dissolved in a few $\mathrm{mL}$ of methylene chloride and loaded onto a Chromatotron plate (Si gel, $2 \mathrm{~mm}$ ). The product was eluted with $2 \% \mathrm{MeOH} /$ $\mathrm{CH}_{2} \mathrm{Cl}_{2}$. The solvent was removed in vacuo to yield a yellow oil, which was redissolved in 10 $\mathrm{mL}$ of 1:1 TFA/ $\mathrm{CH}_{2} \mathrm{Cl}_{2}$ and stirred for one hour. The solution was concentrated to $<1 \mathrm{~mL}$ under a stream of $\mathrm{N}_{2}$ and taken up in ether. The resulting yellow precipitate was isolated by filtration and dried in vacuo to yield $500 \mathrm{mg}$ of the title compound as a yellow powder (95\%). ${ }^{1} \mathrm{H}$ NMR $\left(300 \mathrm{MHz}, \mathrm{CD}_{3} \mathrm{OD}, 25{ }^{\circ} \mathrm{C}\right) \delta=3.05\left(\mathrm{~m}, 1 \mathrm{H}, \mathrm{C}_{\beta}-\mathrm{H}\right), 3.26\left(\mathrm{~m}, 1 \mathrm{H}, \mathrm{C}_{\beta}-\mathrm{H}\right), 4.83\left(\mathrm{~m}, 1 \mathrm{H}, \mathrm{C}_{\alpha}-\mathrm{H}\right)$, $6.72(\mathrm{~m}, 2 \mathrm{H}$, phenol-H), 7.13 (m, 2H, phenol-H), 7.85 (m, 2H, Anq. arom. C-H), 7.97 (m, 1H, NH), 8.12 (m, 1H, Anq. arom. C-H), 8.27 (m, 3H, Anq. arom. C-H), 8.58 (d, 1H, N-H, 1.6 Hz). ESI-MS Calcd (Found): $[\mathrm{M}+\mathrm{H}]^{+} 416.11$ (416.11), $[2 \mathrm{M}+\mathrm{H}]^{+} 831.22$ (831.21). 
The title compound was prepared by the same method as that used for Anq-Y-OH, except that F$\mathrm{O} t \mathrm{Bu} \cdot \mathrm{HCl}$ was used in place of $\mathrm{Y}-\mathrm{O} t \mathrm{Bu}(63 \%) .{ }^{1} \mathrm{H} \mathrm{NMR}\left(300 \mathrm{MHz},\left(\mathrm{CD}_{3}\right)_{2} \mathrm{CO}, 25^{\circ} \mathrm{C}\right) \delta=3.14$, (m, 1H, $\left.\mathrm{C}_{\beta}-\mathrm{H}\right), 3.40\left(\mathrm{~m}, 1 \mathrm{H}, \mathrm{C}_{\beta}-\mathrm{H}\right), 4.93\left(\mathrm{~m}, 1 \mathrm{H}, \mathrm{C}_{\alpha}-\mathrm{H}\right)$, 7.17-7.35 (m, 5H, phenyl C-H), $7.87(\mathrm{~m}$, 2H, Anq. arom. C-H), 8.11 (m, 1H, Anq. arom. C-H), 8.29 (m, 3H, Anq. arom. C-H), 8.58 (d, 1H, Anq. arom. C-H, $1.6 \mathrm{~Hz}$ ), 9.00 (d, 1H, N-H, $8.3 \mathrm{~Hz}$ ). ESI-MS Calcd (Found): $[\mathrm{M}+\mathrm{H}]^{+}$ 400.12 (400.12), $[2 \mathrm{M}+\mathrm{H}]^{+} 799.23$ (799.22)

Synthesis of Chromophore-(Y/F)LVGQIDSEVDTDDLSNFQL [Chromophore-(Y/F)R2C19]. Solid phase peptide synthesis (SPPS) using Fmoc-protected amino acids was employed to extend the Fmoc-R2C19-PEG-PS resin bound peptide, which was available from a previous study. ${ }^{46}$ For the syntheses of the chromophore-(Y/F)-R2C19 peptides, typically $125 \mathrm{mg}$ of the Fmoc-R2C19-PEG-PS resin bound peptide $(0.2 \mathrm{mmol} / \mathrm{g})$ was loaded into a $10 \mathrm{~mL}$ Bio-Rad Poly-Prep column containing a porous $30 \mu \mathrm{m}$ polyethylene bed in the bottom to hold the resin. The N-terminal Fmoc protecting group was cleaved by shaking the resin in a solution of $1.8 \mathrm{~mL}$ 0.1 M HOBt in $20 \%$ piperidine/DMF for $3 \times 8$ min using a FisherScientific Vortex Genie 2 (VWR). The resin was then washed with $3 \times 2 \mathrm{~mL}$ of DMF and $\mathrm{CH}_{2} \mathrm{Cl}_{2}$. Fmoc- $\mathrm{Y}(\mathrm{tBu})-\mathrm{OH} /$ Fmoc-F-OH was then coupled to the free N-terminus by shaking the resin for $2 \times 70-80 \mathrm{~min}$ in a solution of $0.5 \mathrm{M}$ amino acid, $0.45 \mathrm{M}$ HATU and $1 \mathrm{M}$ DIPEA; the volume was adjusted accordingly such that the amino acid was in $6-8$ fold excess. The chromophore-COOH (chromophore $=$ Anq and Fmoc-BPA) compounds were then coupled in a similar manner with the following modifications. In the case of the Anq chromophore, the coupling solution consisted of 4 eq of Anq-COOH suspended/dissolved in 300 - $600 \mu \mathrm{L}$ of DMF containing 0.45 M HATU and $1 \mathrm{M}$ DIPEA due to limited solubility of the chromophore. In the case of Fmoc-BPA, after chromophore coupling, the Fmoc protecting group was cleaved as described above and the Nterminus acetylated by shaking the resin in a $0.5 \mathrm{M}$ acetic anhydride, $0.5 \mathrm{M}$ DIPEA in DMF for 1 hour. Cleavage of the peptide from the resin was carried out by shaking in $2.5 \mathrm{~mL}$ of $95 \%$ TFA, $2.5 \%$ triisopropylsilane, $2.5 \%$ water for $4 \mathrm{~h}$. The resin was then washed for $2 \times 1 \mathrm{~min}$ with $2 \mathrm{~mL}$ 
of TFA. The cleavage cocktail and washings were combined, evaporated under a stream of $\mathrm{N}_{2}$, and taken up in $15 \mathrm{~mL}$ of ether to precipitate the crude peptide, which was pelleted in a centrifuge and the ether decanted. The precipitate was dissolved in $0.1 \mathrm{M}$ ammonium bicarbonate HPLC buffer via sonication over several minutes.

Peptide Purification and Characterization. Peptides were purified by reversed phase HPLC as previously described. ${ }^{29}$ The HPLC system consisted of a Waters 600 controller and a Waters 996 photodiode array detector, which were interfaced to and controlled by a computer using Waters' Millenium 32 software. Samples were manually injected onto a semi-preparative Waters XTerra MS C-18 column $(19 \times 100 \mathrm{~mm})$, which had been previously equilibrated with $10 \%$ acetonitrile/0.1 M ammonium bicarbonate $(\mathrm{pH} 8)$. A linear gradient of $10 \rightarrow 65 \%$ acetonitrile vs. ammonium bicarbonate over $45 \mathrm{~min}$ at a flow rate of $5 \mathrm{~mL} / \mathrm{min}$ was used to elute the peptides. The eluant absorbance was monitored at the $\lambda_{\max }$ of the chromophore and at 210 nm, where the peptide amide bond absorbs. Fractions were collected by hand, lyophilized, taken up in $50 \mathrm{mM}$ Tris buffer at $\mathrm{pH} 7.5$, combined, and stored at $-80{ }^{\circ} \mathrm{C}$. Analytical HPLC was employed to confirm the purity of the peptides. The samples were manually injected onto an analytical Waters XTerra MS C-8 $(4.6 \times 100 \mathrm{~mm})$ column and eluted with the same gradient used for purification at a flow rate of $1 \mathrm{~mL} / \mathrm{min}$. The molecular weight $(\mathrm{MW})$ of the peptide was characterized by MALDI-TOF mass spectrometry as described below. The HPLC retention times $\left(t_{\mathrm{R}}\right)$ and MALDI-TOF $\mathrm{m} / \mathrm{z}$ ratios for each peptide are listed in Table 1. Analytical HPLC traces for each peptide recorded at $210 \mathrm{~nm}$ are shown in Supporting Information (Figures S1-S4).

Isolation, Purification and Pre-reduction of $\alpha 2$. E. coli $\alpha 2$ was isolated by standard procedures. $^{45}$ To remove contaminating $\beta 2$, it was further purified using a POROS HQ/20 anion exchange column (Applied Biosystems) on a BIOCAD Sprint Perfusion Chromatography System (Applied Biosystems). The column was loaded with $\alpha 2$ (10 - $15 \mathrm{mg}$ ) and washed with Tris buffer ( $50 \mathrm{mM}$, pH 7.6) for $5 \mathrm{~min} . \alpha 2$ was eluted with a linear gradient of $0-700 \mathrm{mM} \mathrm{NaCl}$ over $30 \mathrm{~min}$ at a flow rate of $4 \mathrm{~mL} / \mathrm{min}$. Fractions were collected by hand and concentrated on a YM-30 membrane (Millipore). This procedure reduced background turnover of CDP 7 - 8 fold. 
To pre-reduce $\alpha 2, \sim 30 \mathrm{mg}$ were incubated with $30 \mathrm{mM}$ DTT for $30 \mathrm{~min}$ at room temperature. Hydroxyurea, ATP and CDP were added to final concentrations of $30 \mathrm{mM}, 3 \mathrm{mM}$ and $1 \mathrm{mM}$, respectively, and the incubation continued for an additional $20 \mathrm{~min}$. Another $10 \mathrm{mM}$ DTT was added, and the mixture incubated for 10 min and desalted on a G-25 Sephadex column ( $35 \mathrm{~mL}$, $1.5 \times 23 \mathrm{~cm}$ ) pre-equilibrated in $50 \mathrm{mM}$ Tris, $15 \mathrm{mM} \mathrm{MgSO}_{4}, \mathrm{pH} 7.6$.

a2 Activity Assay and Competitive Inhibition Assay for Binding of Peptide to $\alpha 2$. $\alpha 2$ (0.1 $\mu \mathrm{M}$, specific activity $\left.=1900 \mathrm{nmol} \mathrm{min} \mathrm{mg}^{-1}\right), \beta 2\left(0.2 \mu \mathrm{M}\right.$, specific activity $=6800 \mathrm{nmol} \mathrm{min}^{-1}$ $\left.\mathrm{mg}^{-1}\right)$, TR $(30 \mu \mathrm{M})$, TRR $(0.5 \mu \mathrm{M}), \mathrm{NADPH}(0.2 \mathrm{mM}), \mathrm{CDP}(1 \mathrm{mM})$, and ATP $(1.6 \mathrm{mM})$ were combined in $50 \mathrm{mM}$ HEPES, $15 \mathrm{mM} \mathrm{MgSO}_{4}, 1 \mathrm{mM}$ EDTA buffer at $\mathrm{pH}$ 7.6. Enzyme activity was measured by the consumption of NADPH, which was monitored by the decrease in absorbance at $340 \mathrm{~nm}$. This was then repeated with peptide concentrations ranging from 2 - 80 $\mu \mathrm{M}$.

Single Turnover Assays for Photoinitiated Nucleotide Reduction in Peptide- $\alpha 2$ Complexes. The assays were performed by a method modified from that previously reported. ${ }^{29}$ FPLC purified, pre-reduced $\alpha 2\left(20 \mu \mathrm{M}\right.$, specific activity $\left.=1800 \mathrm{nmol} \mathrm{min}{ }^{-1} \mathrm{mg}^{-1}\right)$, peptide $(200$ $\mu \mathrm{M})$, ATP $(3.0 \mathrm{mM})$, and $\left[2{ }^{14} \mathrm{C}\right]-\mathrm{CDP}\left(1.0 \mathrm{mM}, 5445 \mathrm{cpm} \mathrm{nmol}{ }^{-1}\right)$ in $50 \mathrm{mM}$ Tris, $\sim \mathrm{mM}$ $\mathrm{MgSO}_{4}$ buffer at $\mathrm{pH} 7.5$ were added to a $1 \mathrm{~cm}$ quartz micro-cuvette with total solution volume of $200 \mu \mathrm{L}$. Care should be taken in preparation of the peptide stock solutions as they are sensitive to the concentration of $\mathrm{MgSO}_{4}$ and the peptide can precipitate upon addition of solid $\mathrm{MgSO}_{4}$ to the solutions. Typically, the peptide stock solutions were prepared in $50 \mathrm{mM}$ Tris buffer ( $\mathrm{pH} 7.5)$ and diluted into the reaction mixture containing millimolar concentrations of $\mathrm{Mg}^{2+}$. The reaction was initiated by the addition of $\left[2-{ }^{14} \mathrm{C}\right]-\mathrm{CDP}(97 \mathrm{mM})$, quickly mixed, spun down in a minicentrifuge ( $<10 \mathrm{~s}, 2000 \mathrm{~g})$ to consolidate the liquid, and pipetted into the cuvette. Samples were irradiated at room temperature with the focused light from a $1000 \mathrm{~W}$ Xe arc lamp equipped with a $299 \mathrm{~nm}$ long pass and IR filters. Fractions $(60 \mu \mathrm{L})$ were removed at 2, 5 and $10 \mathrm{~min}$ intervals and immediately quenched by heating in a boiling water bath for $2 \mathrm{~min}$. The precipitated protein was then spun down for $10 \mathrm{~min}$ in a minicentrifuge at $20,000 \mathrm{~g}$. The 
supernatant (50 of the $60 \mu \mathrm{L}$ ) was transferred to a new Eppendorf tube, diluted with 14 units of alkaline phosphatase and $120 \mathrm{nmol}$ of carrier $\mathrm{dC}$ to a final volume of $170 \mu \mathrm{L}$, and incubated at 37 ${ }^{\circ} \mathrm{C}$ for $2 \mathrm{~h}$ in a sealed Eppendorf vial. $\mathrm{dC}$ was then separated from $\mathrm{C}$ and quantitated as previously described. ${ }^{47,48}$ Each reaction was repeated twice along with a dark $\alpha 2$ control and a dark $\alpha 2$-peptide control to quantify background counts arising from contaminating $\beta 2$ that copurifies with $\alpha 2$ and from radiochemical impurities in the stock $\left[2-{ }^{14} \mathrm{C}\right]$-CDP that elute with the product. Background counts were low in these experiments, as shown in Table S1. For reactions involving the Y730F- $\alpha 2$ mutant, $90 \mu \mathrm{M}$ peptide and $20 \mu \mathrm{M}$ protein were used, with all other conditions the same as for wt- $\alpha 2$.

Physical Measurements. ${ }^{1} \mathrm{H}$ NMR spectra were recorded on a Varian Mercury $300 \mathrm{MHz}$ NMR at the MIT Department of Chemistry Instrumentation Facility (DCIF) and externally referenced to tetramethylsilane. ESI-FT mass spectrometry was performed with a Brüker Daltonics APEXII instrument housed in the DCIF. MALDI-TOF mass spectrometry was performed with a Brüker Omniflex instrument in the DCIF using $\alpha$-cyano-4-hydroxycinnamic acid as the matrix. The instrument was calibrated in positive ion mode with a quadratic polynomial using a mixture of angiotensin II (1046.5423), P14R synthetic peptide (1533.8582), and ACTH fragment 18-39 (2465.1989) (Sigma). All peptides synthesized were analyzed in negative ion mode due to the large number of carboxylate containing residues.

UV-vis absorption spectra were recorded on a Cary 17D modified by On-Line Instrument Systems (OLIS) to include computer control or a Spectral Instruments 440 spectrophotometer. TA measurements were made with pump light provided by the third harmonic $(355 \mathrm{~nm})$ of an Infinity Nd:YAG laser (Coherent) running at $20 \mathrm{~Hz}$ as previously described. ${ }^{49}$ In the case of the BPA, $300 \mathrm{~nm}$ pump light was used as previously described owing to the lack of absorption at $355 \mathrm{~nm}$ for this chromophore. ${ }^{44}$ Transient absorption experiments for all compounds were performed in a $2 \mathrm{~mm}$ cuvette in $20 \mathrm{mM}$ Tris buffer at $\mathrm{pH} 7.5$ at $350 \mu \mathrm{M}$ for Anq dipeptides/Y(F)R2C19 peptides and $500 \mu \mathrm{M}$ for the BPA dipeptides/Y-R2C19 peptide. Sample volumes of 200 $\mu \mathrm{L}$ were employed for all the peptide spectroscopy experiments reported herein. For transient 
absorption experiments involving Anq-Y-OH, $10 \mathrm{~mL}$ of solution were continuously flowed through a $2 \mathrm{~mm}$ cuvette during data collection to ensure that fresh sample was present for each laser shot. All experiments were performed under ambient conditions.

\section{Results}

Synthesis. Dipeptides containing the chromophore and Y or F were synthesized and their photoreactions examined by TA spectroscopy. The efficacy of the BPA and Anq chromophores as competent photo-oxidants of $\mathrm{Y}$ is more conveniently established with the dipeptides as opposed to full length $\mathrm{R} 2 \mathrm{C} 19$ peptide since the former are more readily synthesized and they offer a simplified photochemistry by avoiding potential side reactions of the chromophore excited states with other residues on R2C19. The BPA-Y-OMe dipeptide synthesis and TA spectroscopy have been reported previously. ${ }^{44}$ The Anq dipeptides are furnished by coupling the carboxylic acid containing Anq- $\mathrm{COOH}$ chromophore to the primary amine of the tert-butyl ester protected amino acid $(\mathrm{F}-\mathrm{O} t \mathrm{Bu}$ and $\mathrm{Y}-\mathrm{O} t \mathrm{Bu})$ using standard peptide coupling conditions. The tertbutyl ester of the amino acid was removed with TFA to yield the free carboxylic acid, thereby improving water solubility of the dipeptide. The UV-vis ground state absorption spectra of BPA$\mathrm{Y}-\mathrm{OMe} \cdot \mathrm{TFA}$ and Anq-Y-OH are shown Figure 3; Anq-Y-OH has a much larger absorption cross section outside of the protein absorption envelope.

Chromophore-(F/Y)-R2C19 peptides were synthesized by extending the Fmoc-R2C19PEG-PS resin bound peptide, first with Fmoc-(F/Y)-OH, followed by the appropriate carboxylic acid containing chromophore (Fmoc-BPA-COOH or Anq-COOH) using standard Fmoc-SPPS conditions. Table 1 lists the HPLC retention times and MALDI-TOF mass spectral data for each of the peptides synthesized. Analytical HPLC traces, obtained by monitoring the absorbance at $210 \mathrm{~nm}$, were used to characterize peptide purity and they are provided for each peptide in Figures S1-S4.

Time-resolved Spectroscopy. The BPA and Anq dipeptides and full-length peptides were weakly emissive or non-emissive in aqueous solutions. Accordingly, the formation and reaction 
of the chromophore excited states and photoproducts were characterized by transient absorption spectroscopy.

The BPA-Y-OMe dipeptide produces the $\cdot$ BPA-Y•-OMe diradical state upon excitation with $\lambda_{\text {exc }}=300 \mathrm{~nm}$. Radical recombination occurs with a rate constant of $5.6 \times 10^{6} \mathrm{~s}^{-1}$. $^{44}$ The transient absorption and kinetics traces shown in Figure 4 establish a similar photochemistry for the full length peptide, Ac-BPA-Y-R2C19. Transient absorption features at 337, 410 and 550 $\mathrm{nm}$, obtained $65 \mathrm{~ns}$ following $300 \mathrm{~nm}$ excitation, are consistent with the formation of $\mathrm{Y} \bullet\left(\varepsilon_{410} \mathrm{~nm}\right.$ $=2750 \pm 200)^{50}$ and the benzophenone radical $\left(\varepsilon_{330 \mathrm{~nm}}=22000 \mathrm{M}^{-1} \mathrm{~cm}^{-1}\right.$ and $\varepsilon_{540 \mathrm{~nm}}=2800 \mathrm{M}^{-1}$ $\left.\mathrm{cm}^{-1}\right) .{ }^{42}$ The triplet of benzophenone is formed with a quantum yield near unity and persists on the microsecond timescale in water. ${ }^{51}$ Thus, we can estimate a near unity quantum yield for formation of the $\cdot \mathrm{BPA}-\mathrm{Y} \bullet$ diradical state. The overall absorption profile does not change over the time course of $415 \mathrm{~ns}, 1 \mu \mathrm{s}$ and $10 \mu \mathrm{s}$. Time-evolved absorption kinetics obtained at 410 and 550 $\mathrm{nm}$ (inset of Figure 4) can both be fit to a mono-exponential decay function with a time constant of $490 \pm 20 \mathrm{~ns}$, thus yielding a rate constant for radical recombination of $2.0 \pm 0.1 \times 10^{6} \mathrm{~s}^{-1}$. The direct and concomitant return of the transient signals of $\bullet$ BPA and $\bullet Y$ to baseline indicates that radical recombination proceeds without the production of additional intermediates. Moreover, the similarity of the transient data for the dipeptide and full-length peptide indicates that the BPA reacts solely with $\mathrm{Y}$ and not other residues on the R2C19 peptide.

The photochemistry of Anq-derivatized dipeptide is more complex. The triplet excited state of 9,10-anthraquinone-2-sulfonate, ${ }^{3} \mathrm{AQS}$, is known to react with water and/or $\mathrm{OH}^{-}$, although the exact photoproducts and reaction mechanism are ill-defined. ${ }^{41}$ Accordingly, the TA spectra of Anq-F-OH were used as a control and compared to that for Anq-Y-OH to distinguish the spectra of the Anq excited state and/or side photoproducts from the products of tyrosine oxidation. Figure 5 (top panel) shows the absorption spectrum obtained 50 ns after Anq-F-OH dipeptide was excited with a 355-nm nanosecond laser pulse. The transient contains a broad feature with $\lambda_{\max } \sim 417 \mathrm{~nm}$ and an even broader and weaker shoulder with $\lambda_{\max } \sim 530 \mathrm{~nm}$. Additional spectra obtained at $100 \mathrm{~ns}, 1 \mu \mathrm{s}$ and $10 \mu \mathrm{s}$ show that the overall profile is invariant 
with time. Analysis of the single wavelength kinetics at $410 \mathrm{~nm}$ reveals a non-exponential decay, which does not return to baseline on the $\mu$ s to ms timescales. This long-lived process is not a result of a photoreaction with the buffer, as similar spectra and kinetics were recorded when Tris buffer ( $\mathrm{pH}$ 7.6) was employed. In light of these results together with the absence of observable triplet phosphorescence, which is normally observed for ${ }^{3} \mathrm{Anq}$ in organic solvents, the spectrum in the top panel of Figure 5 likely arises from a photoreaction between ${ }^{3}$ Anq and water.

The bottom panel of Figure 5 displays the results for a transient experiment performed on Anq-Y-OH under the identical set of experimental conditions employed for Anq-F-OH. The first transient (50 ns) is markedly different from that obtained for Anq-F-OH and contains features with $\lambda_{\max } \sim 520 \mathrm{~nm}$ and $410 \mathrm{~nm}$ and a shoulder at $395 \mathrm{~nm}$. We ascribe the $520-\mathrm{nm}$ absorption to the anthraquinone semiquinone radical anion, Anq ${ }^{-}$, based on similar absorption spectra to that of the native 9,10-anthraquinone semiquinone radical anion $\left(\varepsilon_{395}=7800 \mathrm{M}^{-1} \mathrm{~cm}^{-1}\right.$ and $\varepsilon_{480}=$ $7300 \mathrm{M}^{-1} \mathrm{~cm}^{-1}$ at $\left.\mathrm{p} K_{\mathrm{a}}=5.3\right)^{52}$ and anthraquinone-2-sulfonate semiquinone radical anion $\left(\varepsilon_{400}=\right.$ $8000 \mathrm{M}^{-1} \mathrm{~cm}^{-1}, \varepsilon_{500}=8000 \mathrm{M}^{-1} \mathrm{~cm}^{-1}$ at $\left.\mathrm{p} K_{\mathrm{a}}=3.25\right) .{ }^{53}$ The higher energy TA band is a superposition of two absorptions at $394 \mathrm{~nm}$ and $408 \mathrm{~nm}$; these wavelengths are commensurate with the absorptions of $\mathrm{Y} \bullet\left(\varepsilon_{410 \mathrm{~nm}}=2750 \pm 200\right)^{50}$ and Anq $\bullet^{-}$of the diradical, Anq $\bullet^{-}-\mathrm{Y} \cdot-\mathrm{OH}$, which we propose to result from Y oxidation by the triplet $n \pi^{*}$ excited state of Anq, ${ }^{3}$ Anq. This photochemistry is consistent with the known reactivity of ${ }^{3} \mathrm{Anq}$ with alcohols. ${ }^{54,55}$ The concomitant disappearance of the 410 and $520 \mathrm{~nm}$ transient absorptions (Figure 5, bottom panel) are indicative of radical recombination. A small residual absorbance, evident at times $>10 \mu$, is similar to the transient features observed with Anq-F-OH (Figure 5, top panel). Single wavelength kinetics obtained at $410 \mathrm{~nm}$ and $520 \mathrm{~nm}$ are best fit to a bi-exponential decay function with a short $\left(\tau_{1}=370 \pm 20 \mathrm{~ns}, 80 \%\right)$ and long $\left(\tau_{2}>10 \mu \mathrm{s}, 20 \%\right)$ components. The major, short component of the decay is assigned to the radical recombination between Anq $\bullet^{-}$and $\mathrm{Y}^{\bullet}$ in Anq $\bullet^{-}-\mathrm{Y} \bullet-\mathrm{OH}$, proceeding at $2.7 \pm 0.1 \times 10^{6} \mathrm{~s}^{-1}$. The minor, long component is assigned to the decay of the Anq-solvent photoproduct identified in the TA spectrum of the Anq-F-OH dipeptide (vide supra). 
Against the backdrop of these dipeptide results, the TA spectroscopy for $\mathrm{Y} \bullet$ generation in Anq-Y-R2C19 peptide was investigated. Figure 6 (top) shows the transients obtained 100 ns, 1 $\mu$ s and $10 \mu$ s after excitation of Anq-Y-R2C19 with $355 \mathrm{~nm}$ laser pulse. The spectra are similar to those observed for the Anq-Y-OH dipeptide and are ascribed to the Anq $\bullet^{-}-\mathrm{Y} \bullet-\mathrm{R} 2 \mathrm{C} 19$ diradical state of the peptide. Single wavelength kinetics obtained at $410 \mathrm{~nm}$ and $520 \mathrm{~nm}$ (Figure 6, left and right insets) could be fit to a bi-exponential decay with short, major and long, minor components similar to that for Anq-Y-OH: $410 \mathrm{~nm}, \tau_{1}=540 \pm 30 \mathrm{~ns}(80 \%), \tau_{2}=2.1 \pm 0.3 \mu \mathrm{s}$ $(20 \%) ; 510 \mathrm{~nm}, \tau_{1}=630 \pm 70 \mathrm{~ns}(80 \%), \tau_{2}=2.1 \pm 0.3 \mu \mathrm{s}(20 \%)$. The shorter components are the same within the error of the measurement, and, as with Anq-Y-OH, are attributed to radical recombination between $\mathrm{Anq}^{-}$and $\mathrm{Y} \bullet$ on the peptide with a rate constant of $1.7 \pm 0.3 \times 10^{6} \mathrm{~s}^{-1}$. As with Anq-Y-OH, we attribute the slower component to the decay of the Anq-solvent photoproduct.

To further confirm $\mathrm{Y} \bullet$ formation in Anq-Y-R2C19, the control peptide Anq-F-R2C19 (as with the dipeptides) was examined in an effort to uncover photochemical reactivity arising from that other than Y356 as a number of other residues are potential reductants of ${ }^{3}$ Anq. ${ }^{3} \mathrm{AQS}$ has been shown to oxidize the carboxylate-containing residues of glycyl-glycine dipeptides leading to the formation of the AQS $\bullet^{-}$semiquinone anion radical and the decarboxylated amidomethylene radical. ${ }^{56,57}$ There are five carboxylic acid containing Asp/Glu residues on the R2C19 peptide. In addition, ${ }^{3}$ Anq has also been shown to oxidize alcohols $;{ }^{54}$ both hydroxylcontaining Ser and Thr residues are present on R2C19 as well. The bottom panel of Figure 6 shows the transients observed upon excitation of the Anq-F-R2C19 peptide with $355 \mathrm{~nm}$ excitation at $100 \mathrm{~ns}, 1,10$, and $100 \mu \mathrm{s}$. These transients observed at $100 \mathrm{~ns}$ do not resemble that for Anq-F-OH (Figure 5, top panel). The peaks at 410 and $520 \mathrm{~nm}$ resemble that of Anq ${ }^{-}$. The decay of the signals at 410 and $520 \mathrm{~nm}$ in the bottom panel of Figure 6 are complex, decaying on both the hundreds of nanoseconds and microsecond timescales, with a Anq ${ }^{-}$remaining after 100 $\mu$ s. Because Anq- ${ }^{-}$should be the only absorbing species in the $375-450 \mathrm{~nm}$ spectral region upon excitation of Anq-F-R2C19, this spectrum may be used for the normalization and subtraction of 
the transients following excitation of Anq-Y-R2C19 and Anq-F-R2C19 at $100 \mathrm{~ns}$. The inset in the top of Figure 6 (middle inset) plots the $\Delta \Delta \mathrm{OD}$ for this subtraction. The distinctive $\mathrm{Y} \bullet$ absorption profile, with at peak at $410 \mathrm{~nm}$ and a shoulder to the blue (for reference, compare to Figure 4 with the Ac-BPA-Y-R2C19 system), is obtained. This difference spectrum further supports the contention that $\mathrm{Y} \bullet$ is produced promptly after excitation of Anq-Y-R2C19.

Peptide Binding to $\alpha 2$. To study PCET in $\alpha 2$ by the approach in Figure 2, the chromophore-(Y/F)-R2C19 peptides need to bind to $\alpha 2$. A protocol has been developed by Climent and coworkers ${ }^{27,28}$ to asses binding of $\beta 2 \mathrm{C}$-terminal tail peptides of various lengths to $\alpha 2$. These studies found that (1) the C-terminal peptide tail of $\beta 2$ accounts for most of the binding interaction between this subunit and $\alpha 2$; (2) these peptides are inhibitors of RNR activity by competing with $\beta 2$ for binding to $\alpha 2$; (3) addition of an N-terminal tyrosine to Ac-R2C19 to form Ac-Y-R2C19 results in stronger binding by a factor of $2\left(K_{\mathrm{i}}=40.0\right.$ and $20.0 \mu \mathrm{M}$, respectively); and (4) further addition of residues at the N-terminus, up to R2C37, did not significantly enhance binding. We were interested to know if the addition of a chromophore to the N-terminus of Y-R2C19 significantly perturbs binding from that of the native peptide studies of Climent. To address this issue, we used Climent's methods ${ }^{27}$ to asses binding of the Ac-BPAand Anq-containing peptides.

$\alpha 2$ and $\beta 2$ (0.1 and $0.2 \mu \mathrm{M}$, respectively) were combined and the relative RNR activity was measured as the peptide concentration was increased from 0 to $80 \mu \mathrm{M}$. Under these conditions, the peptide concentrations at $50 \%$ inhibition, $I C_{50}$, can be used to approximate $K_{\mathrm{i}}{ }^{27}$ $I C_{50} \mathrm{~S}$ were estimated from the plots of relative RNR activity vs. peptide concentration shown in Figure 7 and are listed in Table 1. These data show that the presence of the chromophore does not weaken binding. In fact, the Anq-containing peptides bind more strongly by a factor of $\sim 4$ compared to the BPA containing peptides suggesting a hydrophobic interaction between the planar aromatic chromophore and the surface of $\alpha 2$. Furthermore, replacement of the F residue with $\mathrm{Y}$ at position 356 on peptides of the same length results in a doubling of the binding 
strength, suggesting a specific interaction between the hydroxyl group of Y356 and residues in $\alpha 2$.

Photoinitiated Nucleotide Reduction. Having established the $\mathrm{Y} \bullet$ photogeneration and $\alpha 2$ binding, light-initiated nucleotide reduction assays were examined to test whether charge transport occurs across the non-covalent peptide/ $\alpha 2$ complex. To quantitate the maximum amount of dCDP that could be formed under single turnover conditions, $\alpha 2$ was incubated with $\beta 2$ and CDP substrate for $10 \mathrm{~min}$. To determine if the peptide deactivates the enzyme in the dark, $\alpha 2$ was also incubated with the Ac-BPA-Y-R2C19 peptide in the dark for 2 min, followed by 10 min incubation with $\beta 2$ and CDP substrate. Both experiments resulted in 2.1 eq of $\mathrm{dC}$ per dimer of $\alpha 2$ (Table S1); the photoassay data are therefore reported as a percent turnover per eq of monomer, $\alpha$.

Photoinitiated nucleotide reduction was performed under conditions where all the $\alpha 2$ was bound to peptide. The calculation of the percent $\alpha 2$ bound treats the $\alpha 2$ dimer as two separate monomers that each bind one peptide with the same $K_{\mathrm{d}}$. By following the protocol of Climent and coworkers, ${ }^{27}$ the $I C_{50}$ values in Table 1 may be used to approximate $K_{d}$ for the peptide- $\alpha 2$ complex. Under the conditions of the single turnover assays for photoinitiated CDP reduction, $\alpha 2$ is $92 \%$ and $98 \%$ bound by Ac-BPA-Y-R2C19 and Anq-Y-R2C19 peptides, respectively.

The results of the photo-assay for $\alpha 2$ :Ac-BPA-Y-R2C19 and $\alpha 2$ :Anq-Y-R2C19 protein:peptide complexes are presented in Figure 8 and in Table S1. Turnover for wt- $\alpha 2$ was complete by the time the first data point was collected ( 2 minutes), and therefore data collected at subsequent times (i.e., 5 and 10 minutes) were invariant. Accordingly, the data for wt- $\alpha 2$ correspond to the average of 9 data points $(3 \times 2,5$, and 10 minutes $)$. The Ac-BPA-Y-R2C19 and Anq-Y-R2C19 peptides turnover $\alpha 2$ under irradiation at $12.0 \pm 0.6 \%$ and $13.1 \pm 0.6 \%$, respectively (indicated by the open bars in Figure 8), which are well above the background turnover (grey bars) that arises from $\beta 2$ contamination and radiochemical impurities. In an attempt to understand why turnover was limited to $\sim 13 \%$, the activity of $\alpha 2$ was assayed before and after photolysis with the Ac-BPA-Y-R2C19 peptide. At 2 minutes, $\alpha 2$ photolyzed in the 
presence of peptide was found to be completely inactive for nucleotide reduction with $\beta 2$ (Table $\mathrm{S} 1$ ), whereas the $\alpha 2$ from the dark reaction maintained activity up to the final time point of 10 minutes. SDS gels of the dark and light reactions (Figure S5) reveal that the $\alpha 2$ band from the light reaction smeared compared to the dark control, consistent with multiple cross-links of the peptide to $\alpha 2$ and degradation of the protein. These data indicate that either the ${ }^{3} \mathrm{BPA}$ or radical photo-products can deactivate the enzyme by direct reaction with $\alpha 2$.

The photoactivity of the $\alpha 2$ :Ac-BPA-Y-R2C19 protein:peptide complex is perturbed significantly by the replacement of Y730 with phenylalanine. Assuming that the $K_{\mathrm{d}}$ for the $\mathrm{Y} 730 \mathrm{~F}-\alpha 2$ peptide complex is the same as with wt- $\alpha 2, \mathrm{Y} 730 \mathrm{~F}-\alpha 2$ is $80 \%$ bound by the Ac-BPAY-R2C19 peptide under the conditions of the assay. However, the turnover measured for Y730F$\alpha 2$ bound by Ac-BPA-Y-R2C19 after 2 minutes of photolysis is within the background levels of the assay (see Figure 8), indicating that the mutant is inactive towards photoinitiated dCDP production.

\section{Discussion}

The excited states of BPA and Anq are rapid $\left(>10^{8} \mathrm{~s}^{-1}\right)$ phototriggers of $\mathrm{Y} \cdot$ when appended to the 20 -mer peptide C-terminus of $\beta 2$. The modified Y-R2C19 peptides bind to $\alpha 2$ with comparable or larger affinity than Y-R2C19 itself, suggesting a hydrophobic interaction between the chromophore and $\alpha 2$. Light excitation of the $\alpha 2: \mathrm{X}-\mathrm{Y}-\mathrm{R} 2 \mathrm{C} 19$ (X $=$ Ac-BPA or Anq) complex triggers RNR activity, as determined by single turnover assays of $\alpha 2$ in the presence of substrate and effector. In this way, the entire $\beta 2$ subunit of the Class I enzyme can be replaced by a small, redox active peptide for $\cdot \mathrm{C} 439$ radical generation in the active site, in much the same way as $\beta 2$ is replaced by the small adenosylcobalamin cofactor in the Class II RNR enzyme. ${ }^{58}$

The BPA and Anq add to the growing repertoire of $\mathrm{Y} \bullet$ phototrigggers of RNR. Tryptophan may also effect light-initiated activity of $\mathrm{RNR},{ }^{29}$ however, the process does not occur through a discrete excited state. W• radicals are obtained through irreversible photo-

ionization of W, which leads to peptide decomposition. ${ }^{30}$ The TA spectra shown in Figures 4 and 
6 establish that $\mathrm{Y} \cdot$ is transiently generated in BPA- and Anq-containing peptides and that the radical decays $(\tau=500 \mathrm{~ns}$ lifetime) via charge recombination to reform the ground state products. Thus, in the absence of $\alpha 2$, the peptide is stable to excitation. However, we note that benzophenone is commonly used as a photoactive cross-linker for peptide and protein ligation. ${ }^{59}$ Peptide crosslinking to $\alpha 2$ would compete with Y oxidation on Y-R2C19 and may provide an explanation for the limiting turnover of $12-13 \%$, which is comparable to that obtained with the W-based system. ${ }^{29}$

Radical transport from Y356 to C439 in the active site of $\alpha 2$ has been proposed to occur through Y731 and Y730 residues. ${ }^{4}$ Y730F and Y731F- $\alpha 2$ site-directed mutants are inactive and the hydrogen bond network among Y730-Y731-C439 was accordingly proposed to be critical for radical transport in $\alpha 2{ }^{60}$ Photochemical radical generation by $\mathrm{W}$ on the Y-R2C19 peptide bound to $\alpha 2$ supports this contention. ${ }^{29}$ The crystal structure of $\alpha 2$ (Figure 1) shows the Y731-Y730C439 triad to be within hydrogen bonding contact distances, with Y731 at the surface of $\alpha 2 .^{17}$ The peptide region of $\beta 2$ containing Y356 is particularly mobile in that it is not located in the crystal structure of $\beta 2$ or in the structure of $\alpha 2$ with the Y-R2C19 peptide bound. Thus the photooxidant or a mobile $\cdot Y 356$ residue photo-generated on the BPA/Anq-Y-R2C19 peptide bound to $\alpha 2$ could, in principle, interact with Y731. In either case, we can probe the mechanism of radical transport along the Y731-Y730-C439 pathway.

We consider three distinct mechanisms for radical transport in $\alpha 2$; these are summarized in Figure 9: (1) ET superexchange in which an electron tunnels from C439 to •Y731 directly; (2) ET hopping in which the electron hole tunnels from $\bullet Y 731 \rightarrow Y 730 \rightarrow C 439$, forming the protonated $\mathrm{Y730} \bullet^{+}$radical cation as an intermediate; and (3) PCET hopping, in which both an electron and a proton tunnel between the $\cdot Y 731 \rightarrow \mathrm{Y} 730 \rightarrow \mathrm{C} 439$ residues, forming the neutral -Y730 radical as an intermediate. The Y730F- $\alpha 2$ variant provides a convenient way to evaluate these potential mechanisms by independently tuning the electron and proton transfer distances. As described above, the X-ray crystal structure of the Y730F- $\alpha 2$ variant $^{61}$ (Figure 9) reveals that 
the mutation breaks the hydrogen bond network between Y731 and C439 while maintaining the protein fold and the distance among the $\pi$-systems of the aromatic rings.

The results of the Y730F- $\alpha 2$ mutant discount Mechanism (1) as a possibility for radical transport. We contend that superexchange tunneling in this system should be mediated by the $\pi-\pi$ interaction between the aromatic Y731-Y730 residues, rather than via the hydrogen bond network as the latter provides a poor conductor of electronic coupling. ${ }^{62,63}$ The disruption of the proton transfer network should do little then to perturb a direct electron transfer superexchange pathway since the distance between the aromatic residues is preserved. Accordingly, the rates for radical transport, and consequently turnover, would not be expected to differ greatly in wt- $\alpha 2$ or Y730F- 2 2. However, Figure 8, clearly shows that photoinitiated turnover (and thus radical transport) is perturbed in the mutant.

Mechanism (2) relies on ET hopping among aromatic residues, which can prevail for long distance charge transfer in proteins ${ }^{64,65}$ and DNA. ${ }^{66}$ For this case, the "hop" in the Y730F mutant entails ET tunneling from C439 to Y731. The hopping distance increases by $\sim 2.5 \AA$ with the replacement of Y730 with phenylalanine. Using a $\beta=1.1 \AA^{-1}$ for tunneling through a 3-ring pathway, ${ }^{67}$ the increased distance in Y730F- $\alpha 2$ should reduce the rate to $\sim 6 \%$ that of wild type (assuming all parameters equal except for distance). Based on this ET-hopping radical transport rate, an overall activity of $0.8 \%$ would be expected. From the data in Figure 8 and Table S1, turnover with Y730F- $\alpha 2$ is $0.4 \pm 0.1 \%$, which is less than that expected for a direct tunneling or hopping pathway. We note that the $0.1 \%$ error is the lower limit of our detection. As can be seen from the data for the $\alpha 2$ dark control experiment, the $0.4 \%$ activity includes counts from contaminating background radiation (most likely due to radiological impurities in CDP). If the activity is normalized to this background, the Y730F- $\alpha 2$ mutant is essentially inactive.

Of relevance to radical transport by Mechanism (3), the self-exchange reaction between phenoxyl radical and phenol has recently been studied computationally. ${ }^{68,69}$ The reaction occurs within a hydrogen bonded complex and proceeds via a PCET mechanism in which the electron is transferred between orbitals of $\pi$ symmetry on the phenol and the proton is transferred between 
distinct orbitals of $\sigma(\mathrm{O}-\mathrm{H})$ symmetry. ${ }^{68,69}$ As has been discussed, since the electron and proton transport is of different origins, the PCET is not derived from a genuine hydrogen atom transfer but rather from the coupling between the electron and proton. ${ }^{37}$ Inasmuch as the electron and proton tunnel for such transfers, the reaction rates are predicted to be highly dependent on tunneling distance ${ }^{69}$ and, as has been emphasized, the decoupling of electron transfer and proton transfer distances is crucial to probing PCET mechanisms. ${ }^{1,37}$ The Y730F mutation increases the tunneling distance for the proton, assuming that crystallographically unidentified water molecules are not present in the structure, while maintaining the electron transfer distance. The O---S distance from Y731 to C439 is $5.9 \AA$ in Y730F- $\alpha 2$, while in wt- $\alpha 2$ the longest distance between phenol-O and thiol-S atoms is $3.4 \AA$. The attenuation of turnover is consistent with the interruption of the proton transfer pathway, as diagrammatically indicated in Figure 9.

The foregoing analysis points toward a proton-dependent hopping mechanism for radical transport in $\alpha 2$. Higher turnover numbers with wt- $\alpha 2$ compared to that for Y730F- $\alpha 2$ will be critical to further distinguishing between ET (Mechanism (2)) and PCET (Mechanism (3)) hopping mechanisms. We note that the active RNR complex may be an asymmetric dimer, ${ }^{22,70}$ and hence the activity of the peptide- $\alpha 2$ may be limited to $50 \%$ owing to half-site reactivity in $\alpha 2$. To overcome this complication, we are now focusing on direct spectroscopic detection of radicals along the pathway in $\alpha 2$. To this end, the current BPA and Anq containing peptides set a benchmark inasmuch as $\mathrm{Y} \bullet$ may be generated with excitation light that lies to the red spectral side of the protein absorption envelope, and, for BPA, the $\mathrm{Y} \cdot$ absorption feature can be clearly detected. The disadvantages of the BPA and Anq chromophores lie in their complicated photochemistry and propensity towards protein crosslinking/degradation. Future experiments will take advantage of the lower energy metal-to-ligand charge transfer excited states of metal complexes $^{31}$ that are competent for radical generation in conjunction with fluorotyrosine unnatural amino acids. ${ }^{44,71}$ Implementation of the approach described here with these modified peptide constructs is underway. 
Acknowledgement. Financial support for this research was provided by the National Institutes of Health (GM47274 (DGN) and GM29595 (JS)).

Supporting Information Available. Analytical HPLC chromatograms for each peptide synthesized herein; SDS gel analysis of pre- and post- photolyzed Ac-BPA-YR2C19: $\alpha 2$ complexes; and, single turnover photo-initiated CDP reduction assay data in tabular form. This material is available free of charge via the Internet at http://pubs.acs.org. 


\section{Chart 1}
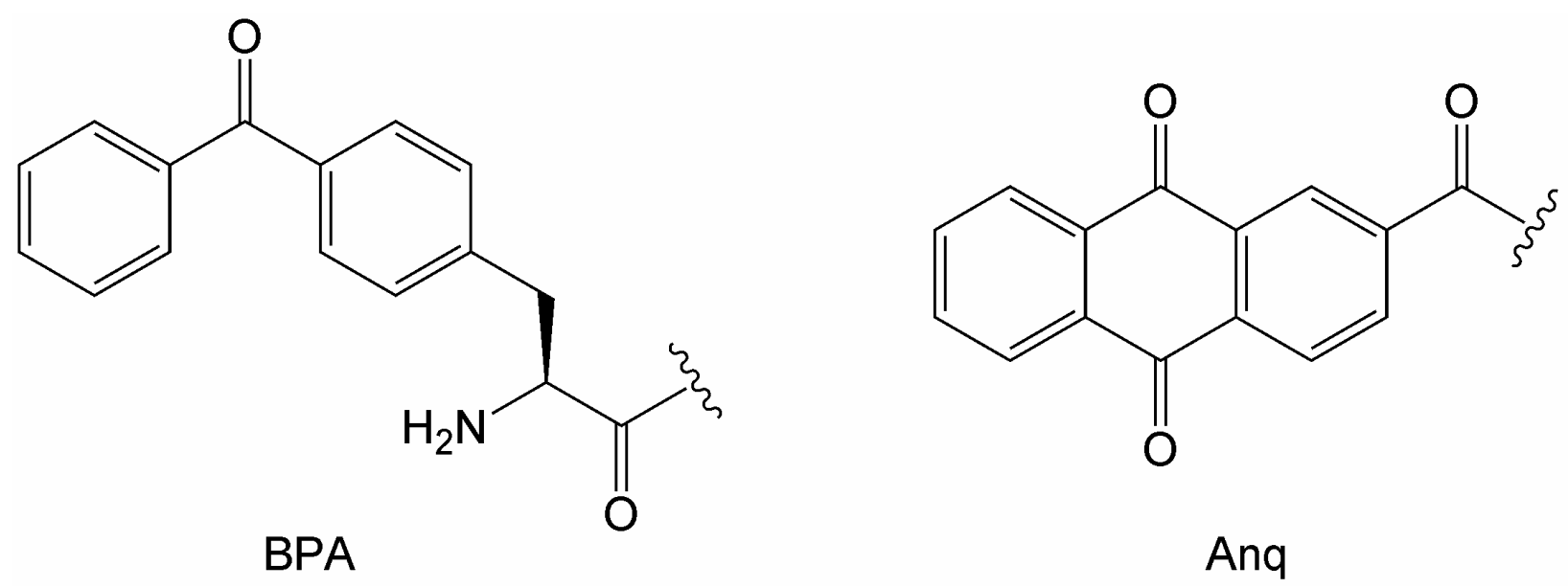
Table 1. Characterization of Peptides

\begin{tabular}{lcccc}
\hline Peptide & $\begin{array}{c}t_{\mathrm{R}} \\
(\mathrm{min})^{a}\end{array}$ & $\begin{array}{c}\text { MW Calcd } \\
(\mathrm{m} / \mathrm{z})\end{array}$ & $\begin{array}{c}\text { MW Found } \\
(\mathrm{m} / \mathrm{z})^{b}\end{array}$ & $\begin{array}{c}I C_{50}{ }^{c} \\
(\mu \mathrm{M})\end{array}$ \\
\hline Ac-BPA-Y-R2C19 & 16.7 & 2563 & 2564 & 15 \\
Ac-BPA-F-R2C19 & 18.3 & 2547 & 2548 & 30 \\
Anq-Y-R2C19 & 17.1 & 2504 & 2507 & 4 \\
Anq-F-R2C19 & 19.9 & 2488 & 2489 & 7 \\
\hline
\end{tabular}

${ }^{a}$ Retention time $\left(t_{\mathrm{R}}\right)$ from analytical HPLC trace. Individual chromatograms are available in the Supporting Information. ${ }^{b}$ MALDI-TOF MS in negative ion mode. ${ }^{c}$ Concentration of peptide at $50 \%$ RNR inhibition. 


\section{References}

1. Reece, S. Y.; Hodgkiss, J. M.; Stubbe, J.; Nocera, D. G. Phil. Trans. Roy. Soc. B 2006, 361, 1351.

2. Mitchell, P. Annu. Rev. Biochem. 1977, 46, 996.

3. Williams, R. J. P. Annu. Rev. Biophys. Biophys. Chem. 1988, 17, 71.

4. Stubbe, J.; Nocera, D. G.; Yee, C. S.; Chang, M. C. Y. Chem. Rev. 2003, 103, 2167.

5. Cukier, R. I.; Nocera, D. G. Annu. Rev. Phys. Chem. 1998, 49, 337.

6. Chang, C. J.; Chang, M. C. Y.; Damrauer, N. H.; Nocera, D. G. Biophys. Biochim. Acta 2004, 1655, 13.

7. Hodgkiss, J. M.; Damrauer, N. H.; Pressé, S.; Rosenthal, J.; Nocera, D. G. J. Phys. Chem. $B$ 2005, 110, 18853.

8. Hammes-Schiffer, S. Acc. Chem. Res. 2006, 39, 93.

9. Stubbe, J.; van der Donk, W. A. Chem. Rev. 1998, 98, 705.

10. Jordan, A.; Reichard, P. Annu. Rev. Biochem. 1998, 67, 71.

11. Stubbe, J. Chem. Comm. 2003, 2511.

12. Thelander, L. J. Biol. Chem. 1973, 248, 4591.

13. Thelander, L.; Reichard, P. Annu. Rev. Biochem. 1979, 48, 133.

14. Kashlan, O. B.; Scott, C. P.; Lear, J. D.; Cooperman, B. S. Biochemistry 2002, 41, 462.

15. Kashlan, O. B.; Cooperman, B. S. Biochemistry 2003, 42, 1696.

16. Stubbe, J.; Riggs-Gelasco, P. Trends Biochem. Sci. 1998, 23, 438.

17. Uhlin, U.; Eklund, H. Nature 1994, 370, 533.

18. Nordlund, P.; Sjöberg, B.-M.; Eklund, H. Nature 1990, 345, 593.

19. Högbom, M.; Galander, M.; Andersson, M.; Kolberg, M.; Hofbauer, W.; Lassmann, G.; Nordlund, P.; Lendzian, F. Proc. Natl. Acad. Sci. U.S.A. 2003, 100, 3209.

20. Bennati, M.; Robblee, J. H.; Mugnaini, V.; Stubbe, J.; Freed, J. H.; Borbat, P. J. Am. Chem. Soc. 2005, 127, 15014. 
21. Seyedsayamdost, M. R.; Yee, C. S.; Reece, S. Y.; Nocera, D. G.; Stubbe, J. J. Am. Chem. Soc. 2006, 128, 1562.

22. Seyedsayamdost, M. R.; Stubbe, J. J. Am. Chem. Soc. 2006, 128, 2522.

23. Hammes-Schiffer, S.; Benkovic, S. J. Annu. Rev. Biochem. 2006, 75, 519.

24. Klinman, J. P. Phil. Trans. Roy. Soc. B 2006, 361, 1323.

25. Bitetti-Putzer, R.; Dinner, A. R.; Yang, W.; Karplus, M. J. Chem. Phys. 2006, 124, 174901.

26. Ge, J.; Yu, G.; Ator, M. A.; Stubbe, J. Biochemistry 2003, 42, 10071.

27. Climent, I.; Sjöberg, B.-M.; Huang, C. Y. Biochemistry 1991, 30, 5164.

28. Climent, I.; Sjöberg, B.-M.; Huang, C. Y. Biochemistry 1992, 31, 4801.

29. Chang, M. C. Y.; Yee, C. S.; Stubbe, J.; Nocera, D. G. Proc. Nat. Acad. Sci. U.S.A. 2004, 101,6882 .

30. Reece, S. Y.; Stubbe, J. S.; Nocera, D. G. Biochim. Biophys. Acta 2005, 1706, 232.

31. Reece, S. Y.; Nocera, D. G. J. Am. Chem. Soc. 2005, 127, 9448.

32. Mayer, J. M. Annu. Rev. Phys. Chem. 2004, 55, 363.

33. Sjödin, M.; Styring, S.; Wolpher, H.; Xu, Y.; Sun, L.; Hammarström, L. J. Am. Chem. Soc. 2005, 127,3855 .

34. Rhile, I. J.; Markle, T. F.; Nagao, H.; DiPasquale, A. G.; Lam, O. P.; Lockwood, M. A.; Rotter, K.; Mayer, J. M. J. Am. Chem. Soc. 2006, 128, 6075.

35. Fecenko, C. J.; Meyer, T. J.; Thorp, H. H. J. Am. Chem. Soc. 2006, 128, 11020.

36. Sjödin, M.; Irebo, T.; Utas, J. E.; Lind, J.; Merényi, G.; Åkermark, B.; Hammarström, L. J. Am. Chem. Soc. 2006, 128, 13076.

37. Hodgkiss, J. M.; Rosenthal J.; Nocera, D. G. In Handbook of Hydrogen Transfer. Physical and Chemical Aspects of Hydrogen Transfer; Hynes, J. T., Klinman, J. P., Limbach, H.-H., Schowen, R. L., Eds; Wiley-VCH: Weinheim, Germany, 2006; Vol. II, Part IV, Ch. 17, p 503. 
38. Ledger, M. B.; Porter, G. J. Chem. Soc. Faraday Trans. 1 1972, 68, 539.

39. Clark, K. P.; Stonehill, H. I. J. Chem. Soc., Faraday Trans. 1 1972, 68, 577.

40. Clark, K. P.; Stonehill, H. I. J. Chem. Soc. Faraday Trans. 1 1972, 68, 1676.

41. Loeff, I.; Treinin, A.; Linschitz, H. J. Phys. Chem. 1983, 87, 2536.

42. Adams, G. E.; Willson, R. L. J. Chem. Soc. Faraday Trans. I 1973, 69, 719.

43. Lathioor, E. C.; Leigh, W. J.; St. Pierre, M. J. J. Am. Chem. Soc. 1999, 121, 11984.

44. Seyedsayamdost, M. R.; Reece, S. Y.; Nocera, D. G.; Stubbe, J. J. Am. Chem. Soc. 2006, $128,1569$.

45. Salowe, S.; Bollinger, J. M., Jr.; Ator, M.; Stubbe, J.; McCraken, J.; Peisach, J.; Samano, M. C.; Robins, M. J. Biochemistry 1993, 32, 12749.

46. Yee, C.S.; Seyedsayamdost, M. R.; Chang, M. C. Y.; Nocera, D. G.; Stubbe, J. Biochemistry 2003, 42, 14541.

47. Steeper, J. R.; Steuart, C. D. Anal. Biochem. 1970, 34, 123.

48. Booker, S.; Licht, S.; Broderick, J.; Stubbe, J. Biochemistry 1994, 33, 12676.

49. Loh, Z.-H.; Miller, S. E.; Chang, C. J.; Carpenter, S. D.; Nocera, D. G. J. Phys. Chem. A 2002, 106, 11700 .

50. Feitelson, J.; Hayon, E. J. Phys. Chem. 1973, 77, 10.

51. Canonica, S.; Hellrung, B.; Wirz, J. J. Phys. Chem. A 2000, 104, 1226.

52. Rao, P. S.; Hayon, E. J. Phys. Chem. 1973, 77, 2274.

53. Hulme, B. E.; Land, E. J.; Phillips, G. O. J. Chem. Soc. Faraday Trans. 1 1972, 68, 1992.

54. Carlson, S. A.; Hercules, D. M. Photochem. Photobiol. 1973, 17, 123.

55. Görner, H. Photochem. Photobiol. 2003, 77, 171.

56. Tarábek, P.; Bonifačić, M.; Beckert, D. J. Phys. Chem. A 2004, 108, 3467.

57. White, R. C.; Tarasov, V. F.; Forbes, M. D. E. Langmuir 2005, 21, 2721. 
58. Sintchak, M. D.; Arjara, G.; Kellogg, B. A.; Stubbe, J.; Drennan, C. L. Nature Struct. Biol. 2002, 9, 293.

59. For example see: Farrell, I. S.; Toroney, R.; Hazen, J. L.; Mehl, R. A.; Chin, J. W. Nature Methods 2005, 2, 377.

60. Ekberg, M.; Sahlin, M.; Eriksson, M.; Sjöberg, B.-M. J. Biol. Chem. 1996, 271, 20655.

61. Eriksson, M.; Uhlin, U.; Ramaswamy, S.; Ekberg, M.; Regnström, K.; Sjöberg, B.-M.; Eklund, H. Structure 1997, 5, 1077.

62. Gray, H. B.; Winkler, J. R. Quart. Rev. Biophys. 2003, 36, 341.

63. Hodgkiss, J. M.; Damrauer, N. H.; Pressé, S.; Rosenthal, J.; Nocera, D. G. J. Phys. Chem. B. 2006, 110, 18853 .

64. Belliston-Bittner, W.; Dunn, A. R.; Nguyen, Y. H. L.; Stuehr, D. J.; Winkler, J. R.; Gray, H. B. J. Am. Chem. Soc. 2005, 127, 15907.

65. Aubert, C.; Vos, M. H.; Mathis, P.; Eker, A. P.; Brettel, K. Nature 2000, 405, 586.

66. Lewis, F. D. In Electron Transfer in Chemistry, Balzani, V., Ed.; Wiley-VCH: Weinheim, Germany, 2001; Vol. 3, Part 1, Ch. 5, p 105.

67. Lee, M.; Shephard, M. J.; Risser, S. M.; Priyadarshy, S.; Paddon-Row, M. N.; Beratan, D. N. J. Phys. Chem. A. 2000, 104, 7593.

68. Mayer, J. M.; Hrovat, D. A.; Thomas, J. L.; Borden, W. T. J. Am. Chem. Soc. 2002, 124, 11142.

69. Skone, J. H.; Soudackov, A. V.; Hammes-Schiffer, S. J. Am. Chem. Soc. 2006, 128, 16655.

70. Seyedsayamdost, M. R.; Stubbe, J. J. Am. Chem. Soc. 2007, 129, 2226.

71. Reece, S. Y.; Seyedsayamdost, M. R.; Stubbe, J.; Nocera, D. G. J. Am. Chem. Soc. 2006, $128,13654$. 


\section{Figure Captions}

Figure 1. Conserved residues of class I RNR that compose the putative PCET pathway for radical transport from $\cdot Y 122$ in $\beta 2$ to $\mathrm{C} 439$ in the $\alpha 2$ active site. Distances are from the separate crystal structures of the $\alpha 2^{17}$ and $\beta 2^{19}$ subunit from the E. coli enzyme. Residues where the radical has been directly observed or trapped via site-specific replacement with non-natural amino acid analogues are highlighted in green. ${ }^{4,22}$ Y356 is not located in either the $\beta 2$ or $\alpha 2$ crystal structures, hence its distance from W48 and Y731 is unknown.

Figure 2. Experimental design for studying the kinetics of radical transport along $\bullet$ Y356 $\rightarrow$ Y731 $\rightarrow$ Y730 $\rightarrow$ C439 pathway. $• Y 356$ is generated photochemically by a proximal photooxidant (red circle) on the R2C19 peptide. NDP, nucleoside diphosphate substrate; dNDP, deoxynucleoside diphosphate product; R2C19, 19-mer C-terminal peptide tail of $\beta 2$.

Figure 3. Ground state UV-vis absorption spectra of BPA-Y-OMe (-,left) and Anq-Y-OH (right). Overlaid in both spectra is the absorption spectrum of $\alpha 2(--)$. The estimated extinction coefficients for BPA-Y-OMe, Anq-Y-OH, and $\alpha 2$ are 2300, 2900, and $22000 \mathrm{M}^{-1} \mathrm{~cm}^{-}$ ${ }^{1}$ at $300 \mathrm{~nm}$ and $\sim 50,2600$, and $4200 \mathrm{M}^{-1} \mathrm{~cm}^{-1}$ at $355 \mathrm{~nm}$, respectively.

Figure 4. Transient absorption spectra of BPA-Y-R2C19 obtained $65(-), 415 \mathrm{~ns}, 1$, and $10 \mu \mathrm{s}$ (-) following $300 \mathrm{~nm}$ excitation. Insets: Time-evolved absorbance data (०) with monoexponential decay fit (-) obtained at 410 and $550 \mathrm{~nm}$.

Figure 5. Top panel: Transient absorption spectra of Anq-F-OH obtained 65 (-), 115 ns, 1, and $10 \mu \mathrm{s}$ (-) following $355 \mathrm{~nm}$ excitation. Bottom: Transient absorption spectra of Anq-Y-OH obtained $15(-), 115 \mathrm{~ns}, 1$, and $10 \mu \mathrm{s}(-)$ following $355 \mathrm{~nm}$ excitation. Insets: Time-evolved absorbance data (०) with bi-exponential decay fit (-) obtained at 410 and $520 \mathrm{~nm}$.

Figure 6. Top panel: Transient absorption spectra of Anq-Y-R2C19 obtained 115 ns (-), 1, and $10 \mu \mathrm{s}(-)$ following $355 \mathrm{~nm}$ excitation. Left and right insets: Single wavelength kinetics traces 
( $\circ$ ) with bi-exponential decay fit (-). Middle inset: Plot of $\Delta \Delta \mathrm{OD}$ obtained by subtracting the normalized transients observed for Anq-Y-R2C19 and Anq-F-R2C19 at 100 ns. Bottom panel: Transient absorption spectra of Anq-F-R2C19 obtained $115 \mathrm{~ns}(-), 1,10$, and $100 \mu \mathrm{s}(-)$ following $355 \mathrm{~nm}$ excitation.

Figure 7. Plots of relative RNR activity vs. peptide concentration in the competitive inhibition binding assay for Ac-BPA-Y-R2C19 (घ), Ac-BPA-F-R2C19 (), Anq-Y-R2C19 (•), and Anq-FR2C19 (o) peptides.

Figure 8. Light initiated, single turnover assays with Ac-BPA-(Y)-R2C19: $\alpha 2$, Anq-Y-R2C19: $\alpha 2$ and Ac-BPA-Y-R2C19:Y730F- $\alpha 2$. The bars refer to light ( $\square$ ) reactions and dark ( $\square)$ controls. For $100 \%$ turnover, each dimer of $\alpha 2$ would produce 2 molecules of dCDP.

Figure 9. The crystal structure of the Y730F- $\alpha 2$ variant shows that mutation of Y730 to F730 interrupts the hydrogen bond network in $\alpha 2$ and significantly increases the proton tunneling distance. Y356 on the R2C20 peptide is not located in the structure and is represented here for illustrative purposes. 
Figure 1

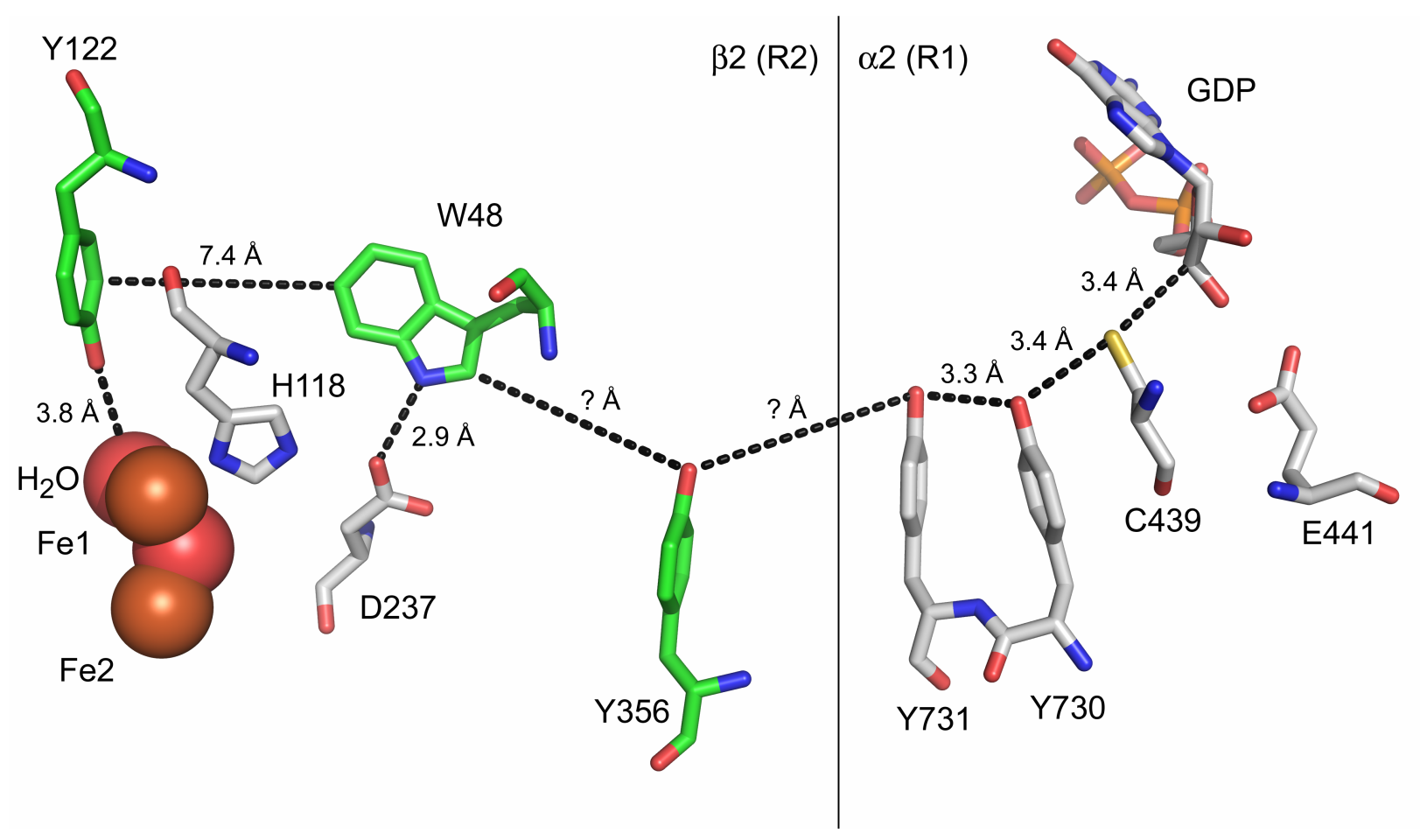


Figure 2
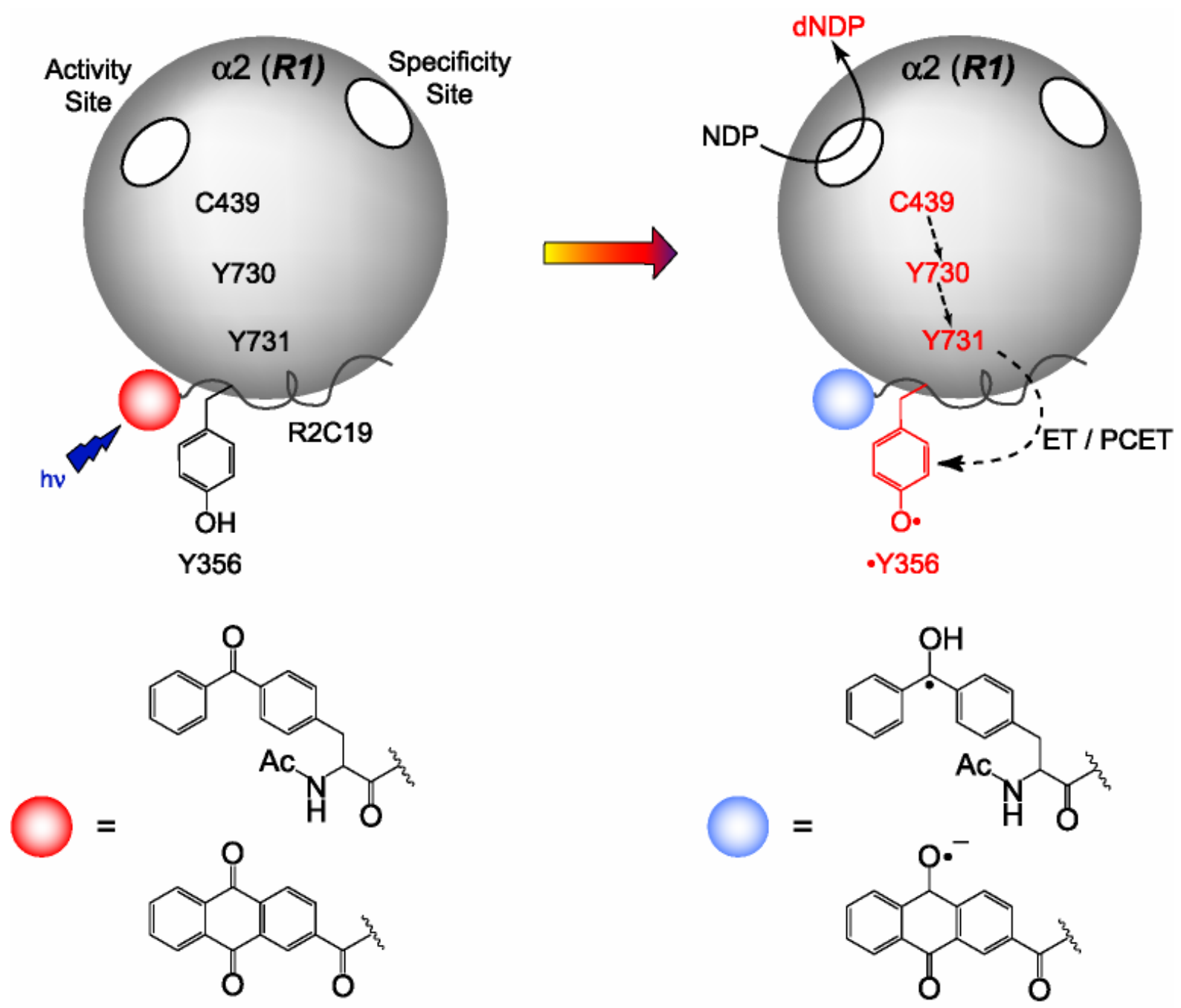
Figure 3

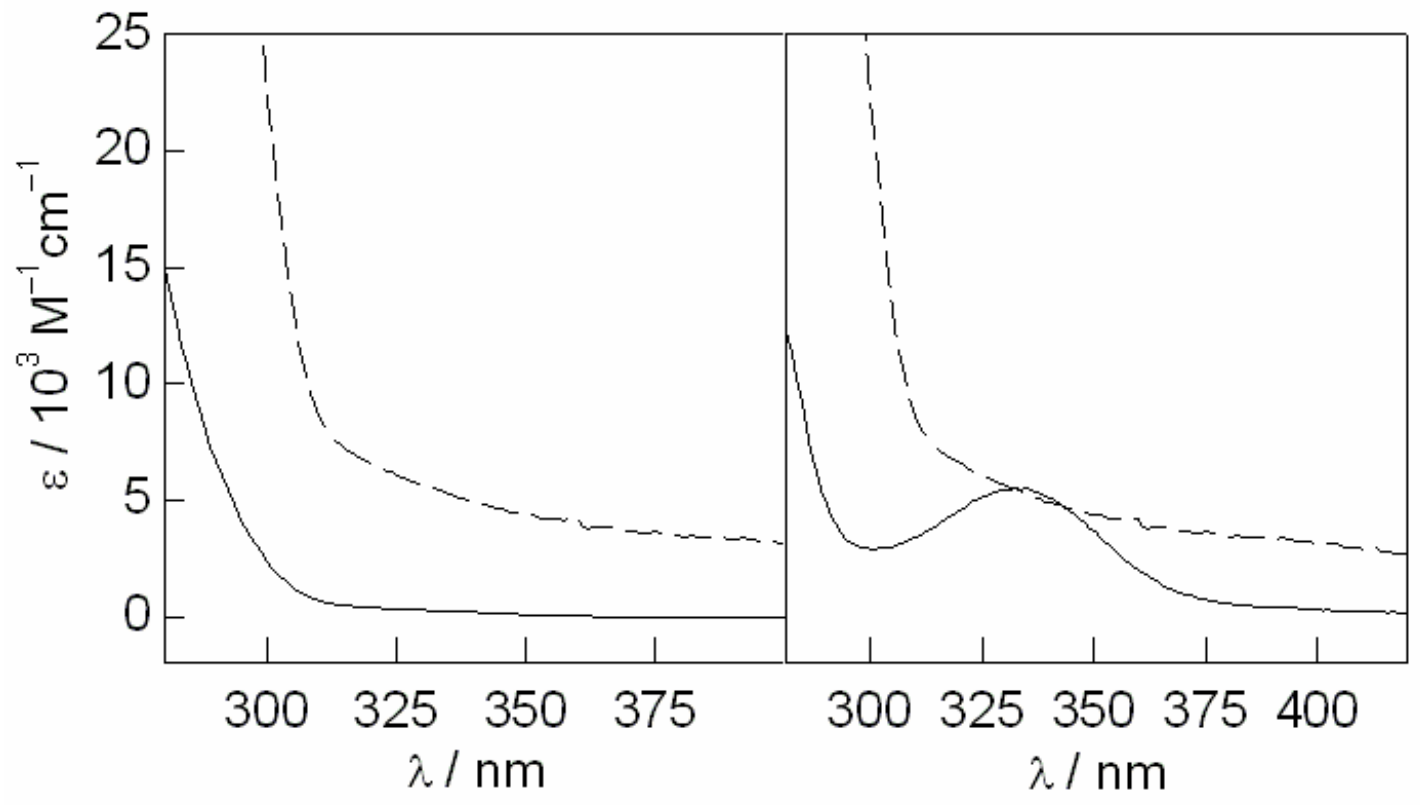


Figure 4

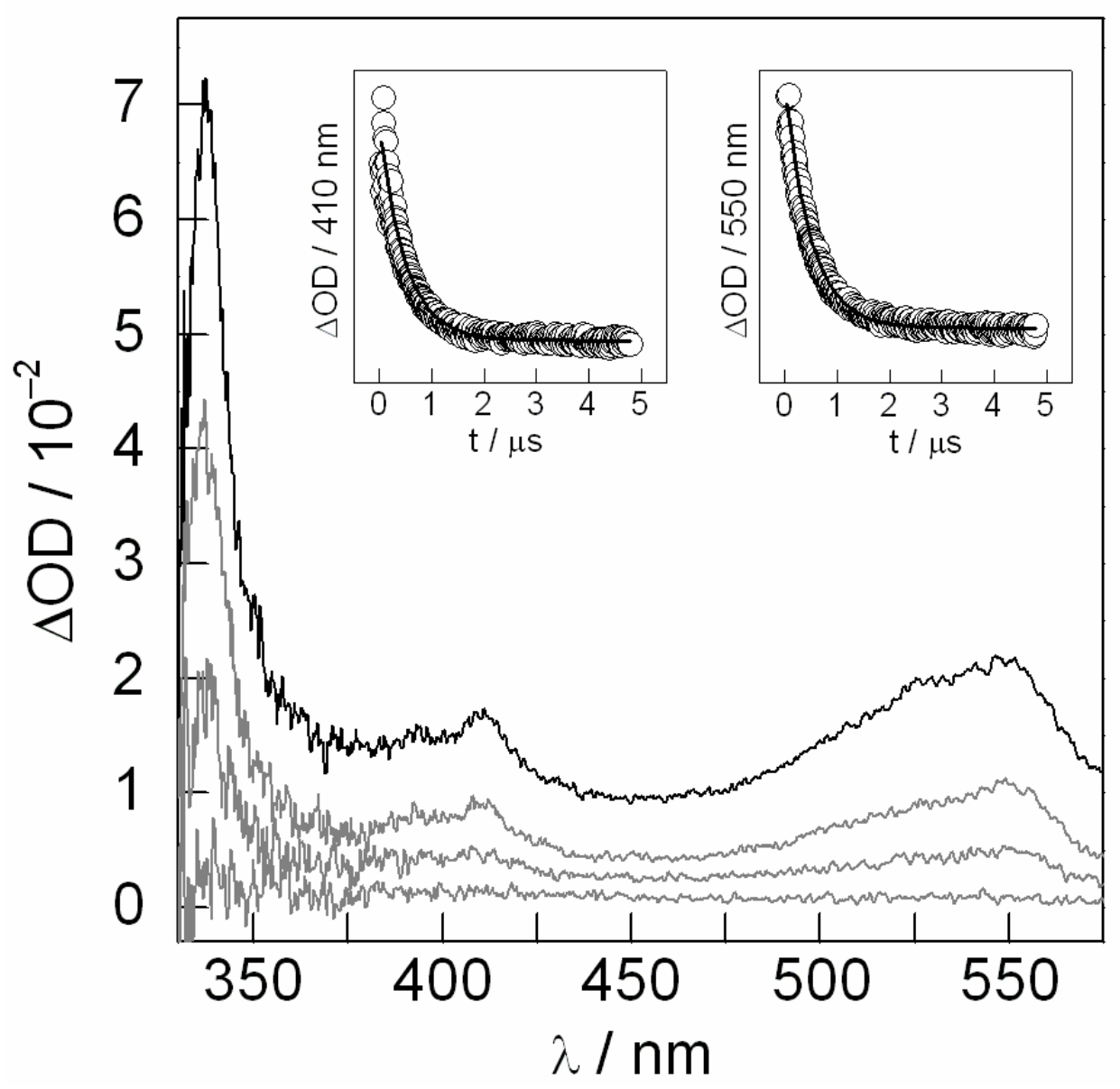


Figure 5

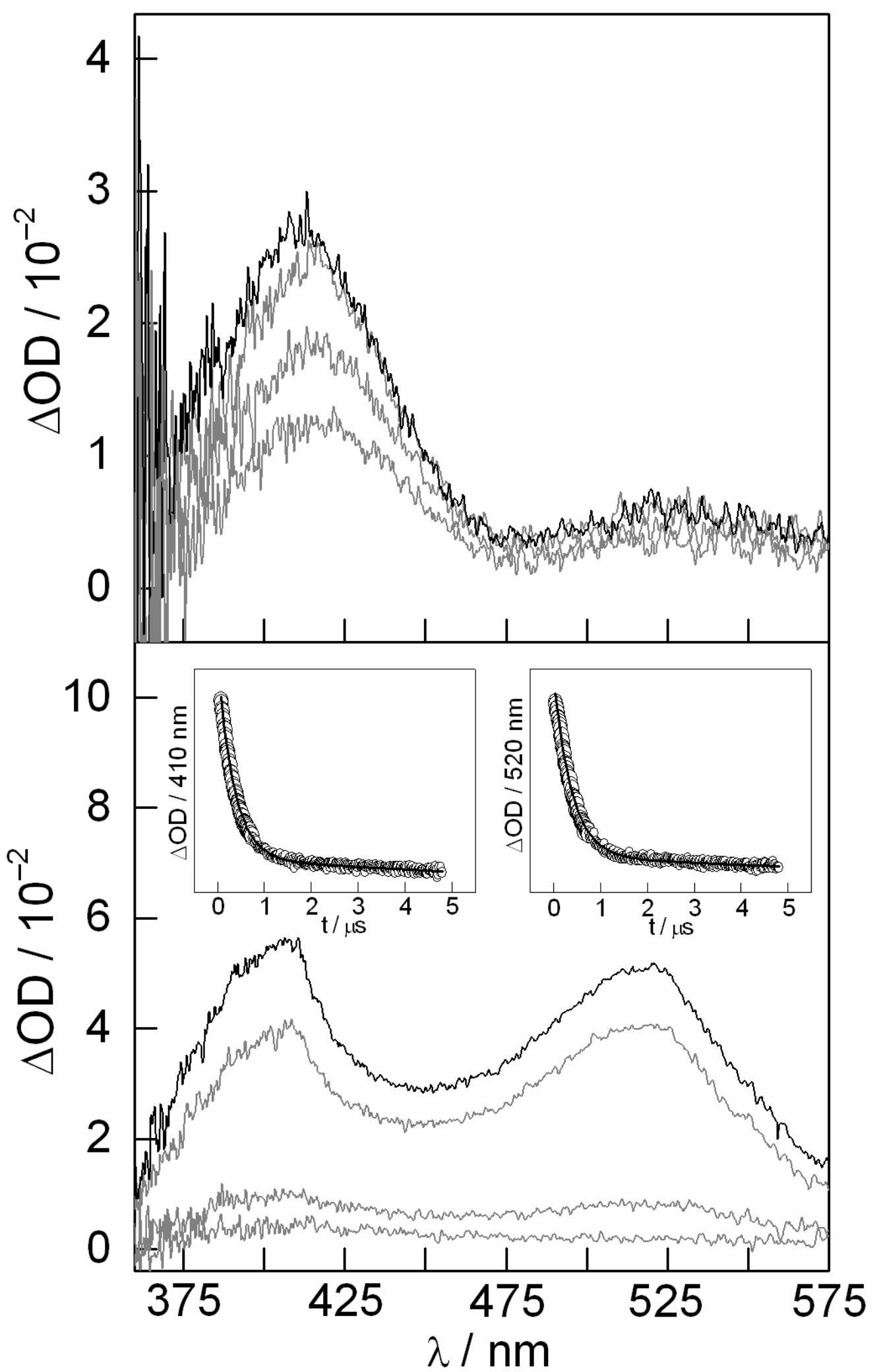


Figure 6
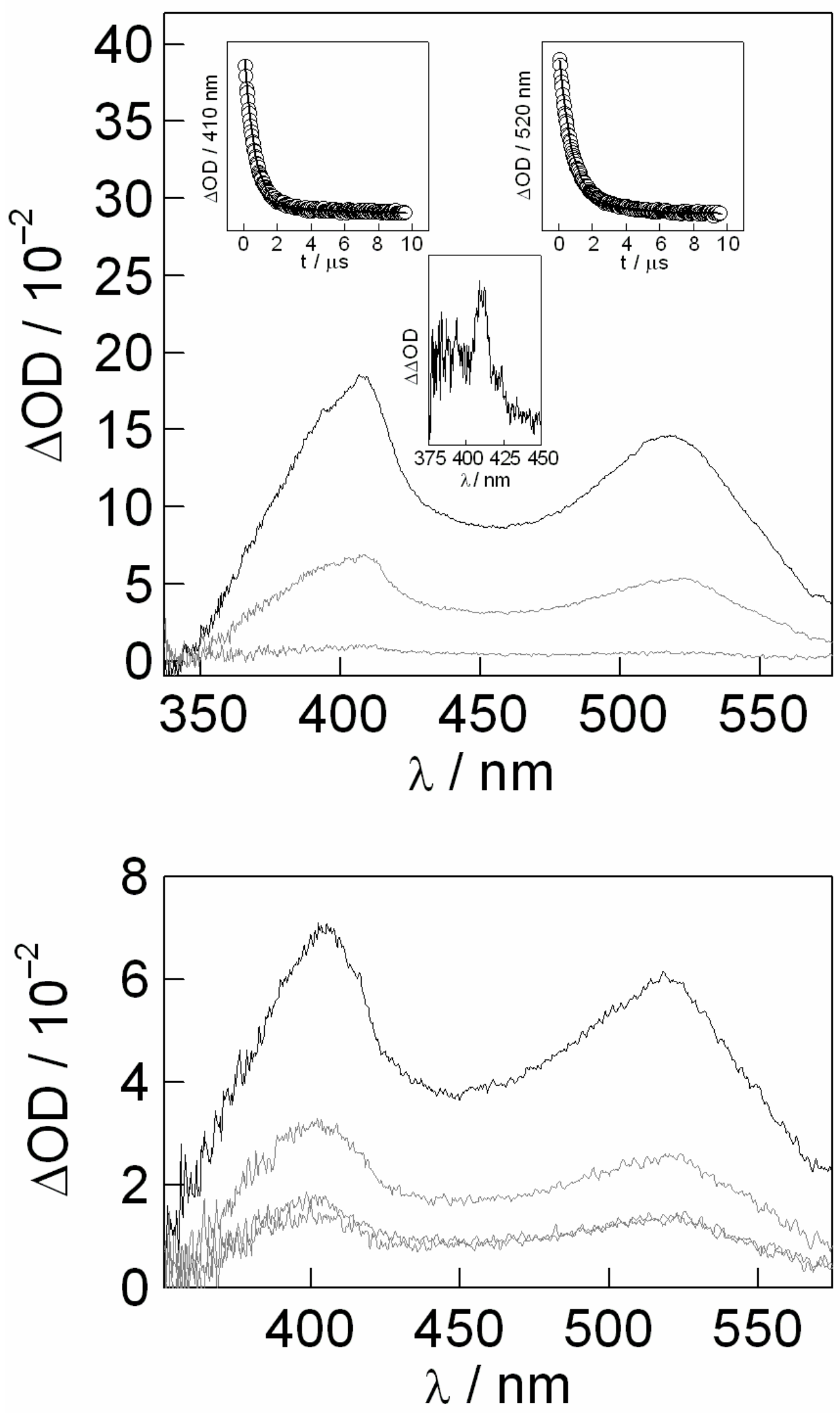
Figure 7

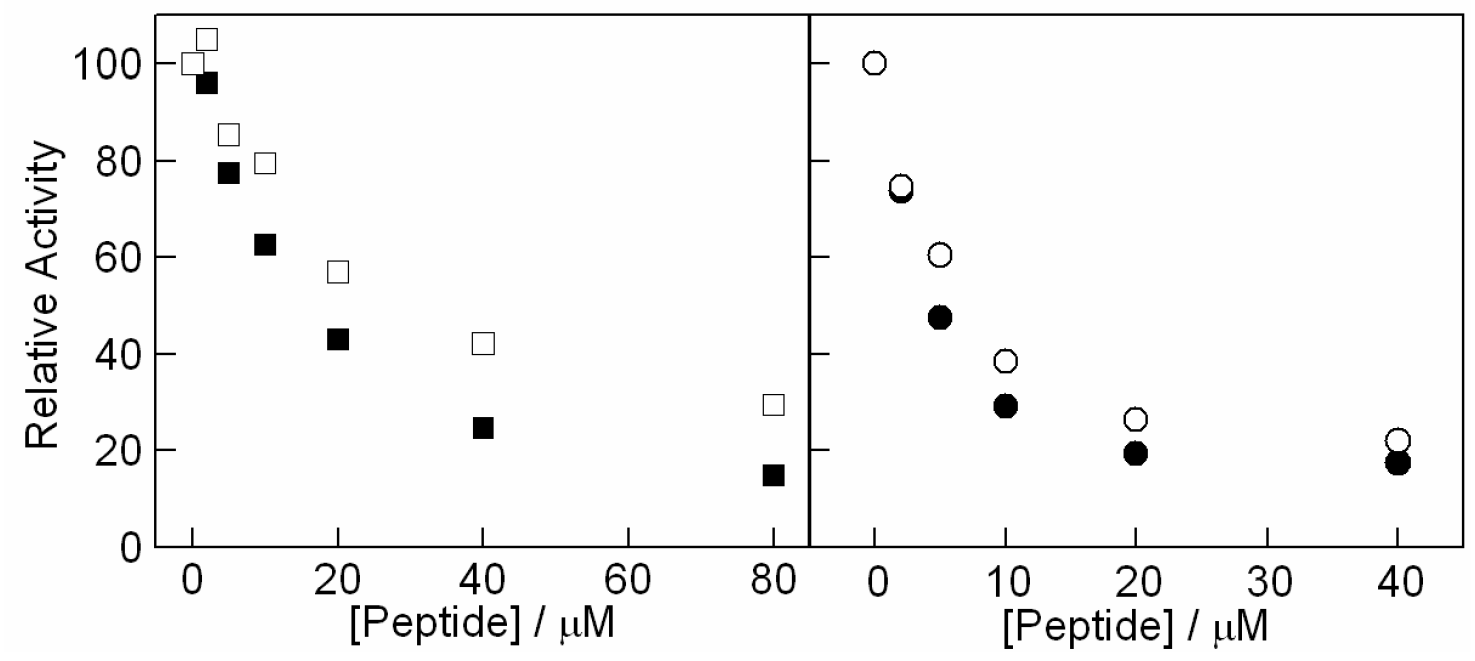


Figure 8

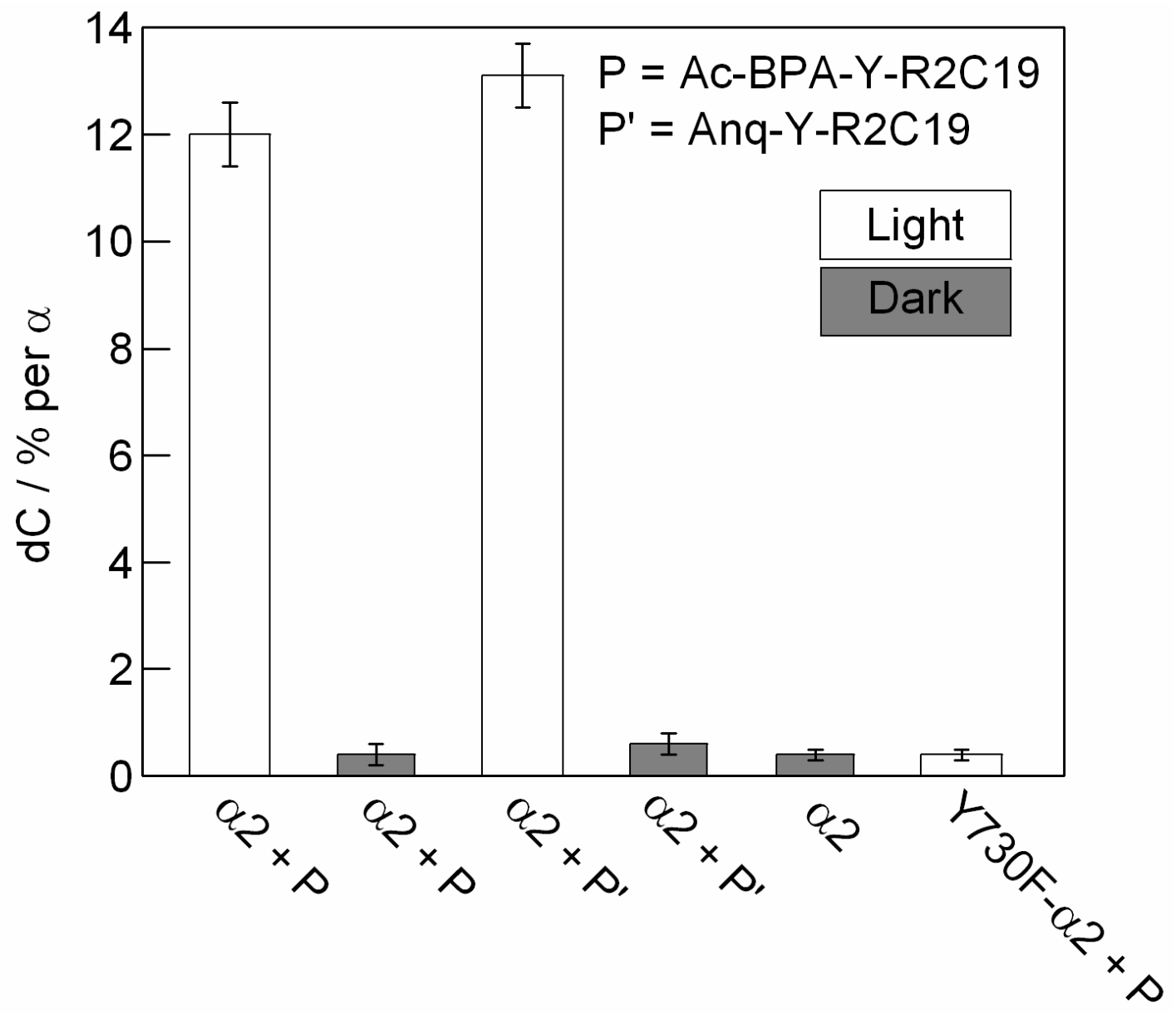




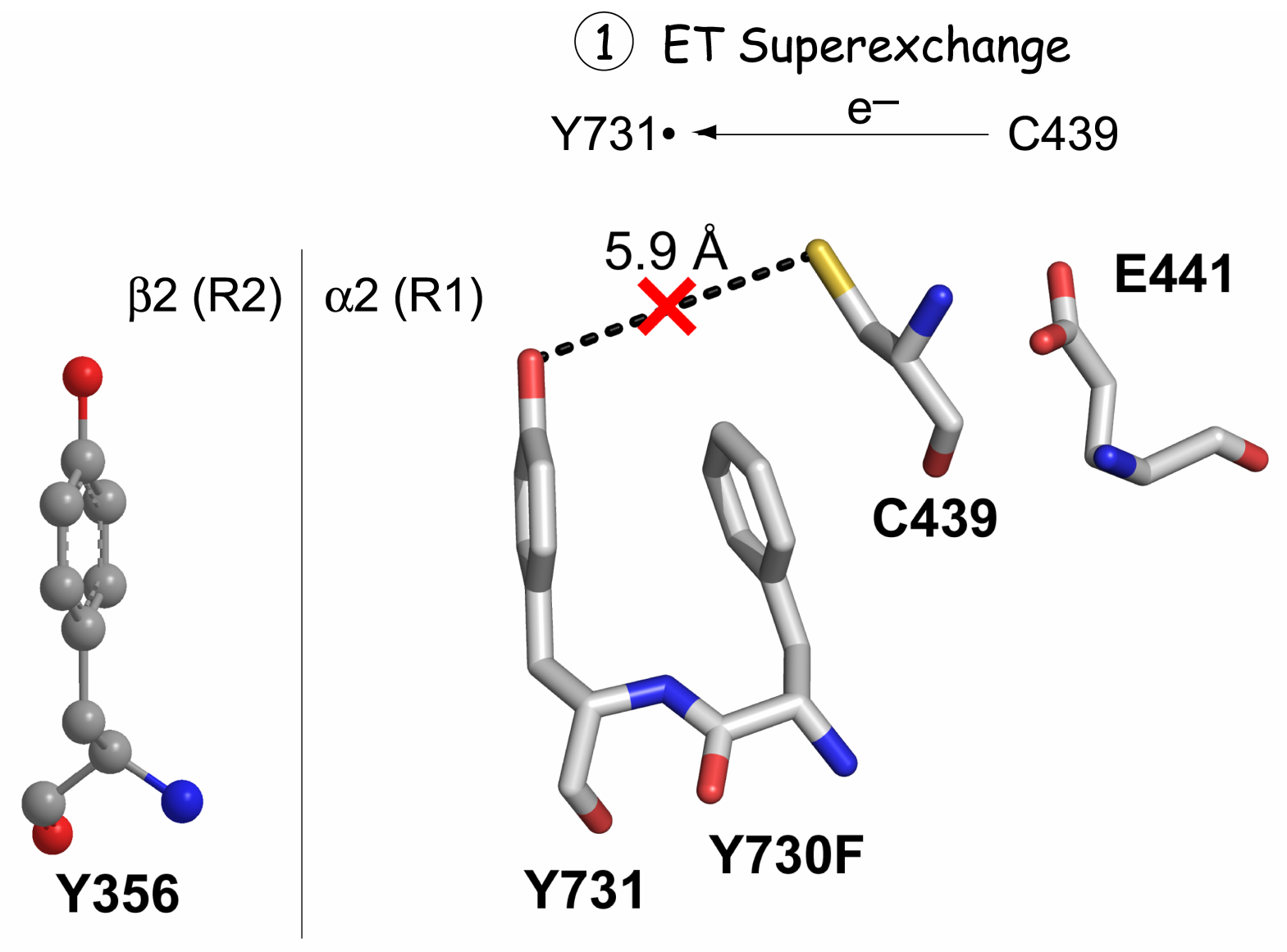

$$
\begin{gathered}
\text { (2) ET Hopping } \\
\text { Y731• } \stackrel{\mathrm{e}^{-}}{\longleftarrow} \mathrm{Y} 730 \stackrel{\mathrm{e}^{-}}{\longleftarrow} \text { C439 } \\
\text { (3) PCET Hopping } \\
\mathrm{Y731} \stackrel{\frac{\mathrm{e}^{-}}{\mathrm{H}^{+}} \mathrm{Y} 730 \stackrel{\mathrm{e}^{-}}{\mathrm{H}^{+}} \text {C439 }}{ }
\end{gathered}
$$




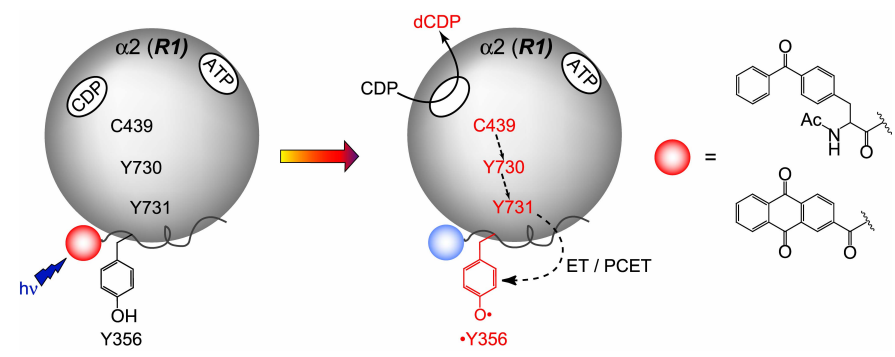

